\title{
The Role of Spain in the Development of the Reef Brachiopod Faunas During the Carboniferous
}

\author{
COR F. WINKLER PRINS
}

Nationaal Natuurhistorisch Museum Naturalis, P.O. Box 9517, 2300 RA Leiden, The Netherlands, winkler@nnm.nl

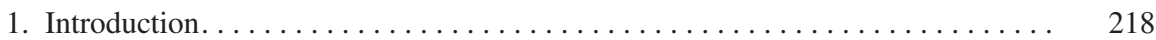

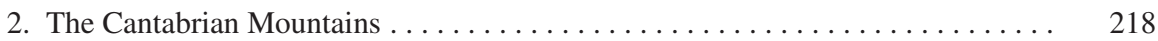

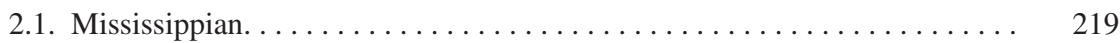

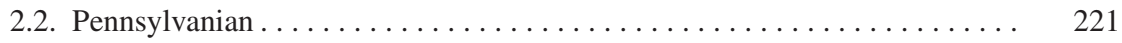

3. Discussion of the Brachiopod Faunas from the Cantabrian Mountains . . . . . . 224

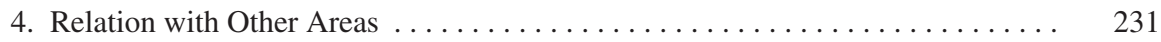

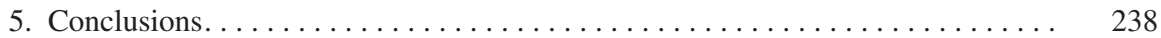

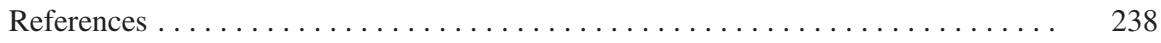

\begin{abstract}
After a short introduction on the reef development during the Late Palaeozoic, the tectono-stratigraphic history of the Cantabrian Mountains (northern Spain) during the Carboniferous is discussed, with an emphasis on the tectonically active Pennsylvanian (i.e., Late Carboniferous). The reef-bearing Valdeteja, San Emiliano, and Cuera formations are briefly described, and their brachiopod faunas are discussed with special emphasis on adaptations to a reef environment. The brachiopod faunas are compared with similar faunas from carbonate-platform deposits with reef structures of Mississippian (i.e., Early Carboniferous) age from Northwest Europe (the British Isles in particular), with Pennsylvanian-Permian faunas from the Alps, Urals, Spitsbergen and Arctic Canada, and with Permian reef faunas from Texas (USA). The Bashkirian brachiopod faunas of the Valdeteja Formation resemble the similarly aged Hare Fiord fauna from Arctic Canada most. This makes one wonder whether the connection between the Palaeotethys and Arctic Canada was through the Urals sea and Arctic, as generally believed, or whether there was another connection from the Cantabrian Mountains to the north along eastern North America.
\end{abstract}




\section{Introduction}

After the Devonian crisis (Eder and Franke, 1982; Webb, 2002) reefs, and especially coral reefs, had become rather rare due to cooling associated with the shift from "greenhouse" to "icehouse" global climate. In the Mississippian, reefs were still reasonably common in Northwest Europe (e.g., Stubblefield, 1960; Bridges et al., 1995; Lees and Miller, 1995; Aretz, 2002). In the Pennsylvanian, further cooling and the influx of siliciclastic material prevented reef forming in most regions, such as Northwest Europe with its paralic deposits. According to Twenhofel (1950) the rarity of Pennsylvanian reefs over large parts of North America was due to muddy water. In the Pennsylvanian, reef structures developed in Texas (West, 1988) leading to the large Permian reef complexes. The Cantabrian Mountains of northwest Spain provide an exceptional example of Pennsylvanian reef mound development (Webb, 2002; Wahlman, 2002). During the entire Carboniferous, the biogenic structures on carbonate platforms were mainly formed by calcareous algae, bryozoans, pelmatozoans, and (chaetetid) sponges (Sommerville et al., 1996; Minwegen, 2001; Wahlman, 2002), although small coral reefs did occur (e.g., Rodríguez, 1996; Aretz and Herbig, 2003; Sano et al., 2004; García-Bellido and Rodríguez, 2005). Associated faunas, brachiopods in particular, sometimes show peculiarities, which may suggest an adaptation to reef environment (e.g., Mundy and Brunton, 1985; Brunton and Mundy, 1988). The presence of closely related or similar forms among the rich brachiopod faunas from the Permian reefs of Texas (Cooper and Grant, 1972-1977) support this interpretation.

In the present paper it is intended to show the importance of the Pennsylvanian (brachiopod) faunas from the Cantabrian Mountains for the survival of these faunas from the Mississippian into late Pennsylvanian and Permian. To explain the special position of these faunas, the geological history of the Cantabrian Mountains during the Devonian and Carboniferous is summarised with special emphasis on the Pennsylvanian, a period of tectonic activity in that area.

\section{The Cantabrian Mountains}

The Palaeozoic core of the Cantabrian Mountains in northwestern Spain (Cantabrian Zone of Lotze, 1945) represents an arcuate fold belt (Fig. 1), which consists of thrust slices and small nappes caused by diastrophic movements of various Carboniferous ages, resulting from a tightening of the arc. The further subdivision of the Cantabrian Zone, as proposed by Julivert (1967, 1971), reflects major faults in the area constituting a single palaeogeographical region. The thrust structures have been moulded around a foreland spur that became more and more restricted to the east as time went by (see Wagner and Martínez García, 1974; Wagner, 2004). This foreland massif was called the Cantabrian Block by Radig (1962). The general region of the Picos de Europa represents the more permanently stable area in which carbonate sedimentation was the norm throughout the Carboniferous. During the Early Palaeozoic a strongly subsident basinal area was situated in the West 


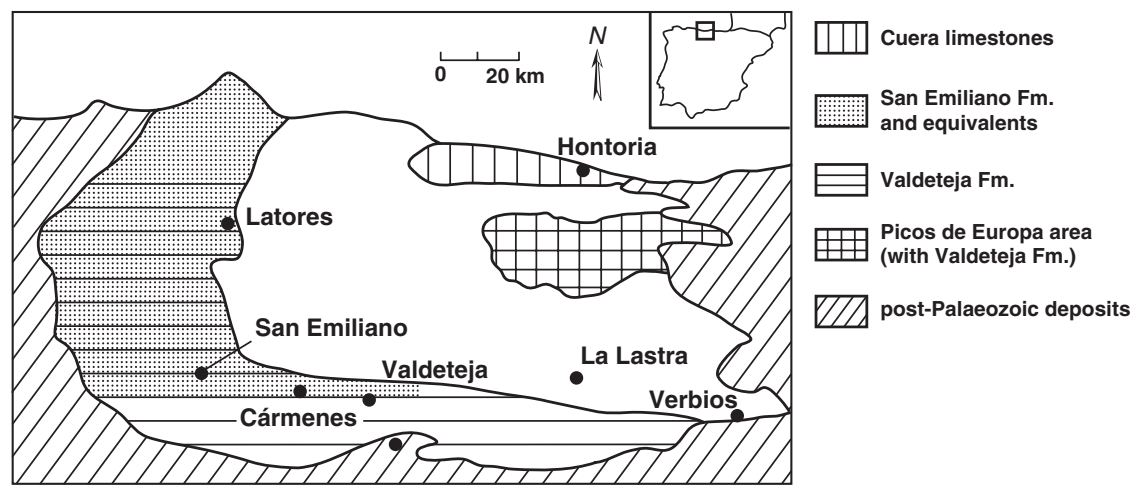

Fig. 1 Map of the Cantabrian Mountains, northwest Spain, showing the areas of deposition of the Valdeteja and San Emiliano formations, Cuera Limestones, and the Picos de Europa (based on data from Eichmüller and Seibert, 1984; Rodríguez Fernández, 1993; Sánchez de Posada et al., 1998; and Wagner and Winkler Prins, 1999). The Carboniferous formations crop out in thrust sheets showing near vertical successions ranging in age from Cambrian to Carboniferous.

Asturian-Leonese Zone (Lotze, 1945), receiving sediment from an enveloping hinterland to the west and south. It moved to the Cantabrian Zone during the Pennsylvanian. The Palaeozoic edifice is covered by an unconformable succession of highest Pennsylvanian (Stephanian C), Permian, Mesozoic, and Cenozoic sediments. A discussion of the different views on the complicated tectonics of the Cantabrian Mountains is beyond the scope of this paper.

The Devonian and Carboniferous deposits of the Cantabrian Zone can be divided into two sedimentary areas, the Asturo-Leonese and Palentian realms, which are separated by the Ruesga Fault, a line of major shortening due to the tightening of the arcuate fold belt (Wagner and Winkler Prins, 1999). I will practically confine myself to the Asturo-Leonese succession. During the Devonian, the southern and western part of the Asturo-Leonese realm subsided most, providing a complete succession with reef development in the Lower-Middle Devonian (e.g., Brouwer, 1964; Mohanti, 1972; Becker et al., 1979; Frankenfeld, 1982; Méndez-Bedia et al., 1994). Towards the north(east) a tectonic high developed and the formations wedge out in that direction. This is at least partly due to a phase of uplift during the Famennian (Comte, 1938; Parga, 1969; Reijers, 1973). The unconformable late Famennian - early Tournaisian Ermita Formation consists largely of sandstones derived from erosion of the underlying deposits.

\subsection{Mississippian}

After this phase of erosion, which lasted until the early Tournaisian, the whole area was leveled and covered by a quiet sea with an anaerobic mud floor (Vegamián Formation), surrounded by an area with limestone development (Baleas Formation; 
see Wagner et al., 1971; Eichmüller and Seibert, 1984: Fig. 3). The Vegamián faunas are either pelagic (e.g., entomozoid ostracodes; Jordan and Bless, 1970) or consist of small invertebrates, concentrated at certain levels, that may represent material drifted in after a storm, perhaps attached to seaweed (cf. Amler and Winkler Prins, 1999; Winkler Prins and Martínez Chacón, 1999), with a connotation of quiet water below wave base (Winkler Prins, 1991; Martínez Chacón and Winkler Prins, 1993). Sediment supply diminished and practically stopped during the deposition of the succeeding Genicera Formation (also called Alba Formation), a succession of nodular to wavy bedded (griotte) limestones of greenish-grey and pink colours, usually enclosing a dark red chert layer (varying from black to white through bleaching), called the Lavandera Member (Wagner et al., 1971). This suggests that the hinterland area was peneplained and probably flooded most of the time. The Genicera Formation contains characteristically large ammonoids and is rich in conodonts. Radiolaria are also found (as in the phosphatic nodules of the Vegamián Formation) and foraminifera, which indicate a gradual deepening in upward succession (Balthasar and Amler, 2003). The faunas, including brachiopods, trilobites, corals, and molluscs are again indicative of a quiet water environment, but - oddly enough - large crinoids (belonging to the genus Balearocrinus) and a large brachiopod, i.e., typical Martinia glabra, do occur as well (Amler and Winkler Prins, 1999). The top of the Genicera Formation reaches the early Serpukhovian (Arnsbergian), when it is succeeded gradually by dark grey, laminated, fetid limestones of the Barcaliente Formation of Serpukhovian to earliest Bashkirian Age, representing turbidites in a starved basin (allodapic limestones of Reuther, 1977: 50). Subsidence increased, since during the Serpukhovian 50-200 m of limestone were deposited as compared to the less than $50 \mathrm{~m}$ for the combined Tournaisian and Viséan. The basin became shallower towards the top of the formation, where breccias (Porma Breccia of Reuther, 1977) and (replaced) gypsum crystals suggest sedimentation in a very shallow, probably intertidal sea (Winkler Prins, 1968: 59; Eichmüller, 1986). Also, the hinterland probably started to rise, as indicated by the development of siliciclastic turbidites replacing the lower part of the Barcaliente Formation in the extreme south (Olleros Formation), at the same place where the top part of the Genicera Formation is replaced by red fossiliferous shales (the Olaja beds; see Wagner et al., 1971: Fig. 6). These are the first signs of the strong tectonic movements that dominated the Cantabrian Mountains during the Pennsylvanian, when a cumulative thickness of some $16,000 \mathrm{~m}$ of flysch and molasse type sediments were deposited.

Fossils are extremely rare in the Barcaliente Formation, but conodonts have been found (Méndez and Menéndez Álvarez, 1985). A conodont fauna typical for the basal Bashkirian of Central Asia has been found at an atypical succession (Palentian facies) near La Lastra in northern Palencia (Nemyrovska, Personal communication 2005). At the La Lastra section no change in the sedimentation can be noticed at the mid-Carboniferous boundary, normally connected with an important eustatic lowering of the sea level. On the other hand, it is possible that the intertidal deposits with collapse breccias in the upper part of the Barcaliente Formation (spectacular examples of which are found in the type section in the Curueño Valley with blocks of $1 \mathrm{~m}^{3}$ in a white spar matrix, see Winkler Prins, 1971) are linked to this event. 


\subsection{Pennsylvanian}

During the larger part of Bashkirian times thick carbonate platform deposits were laid down around a central, more stable area. These platform deposits include reef limestones (Winkler Prins, 1968; Eichmüller and Seibert, 1984; Minwegen, 2001) of the Valdeteja Limestone Formation succession (675 $\mathrm{m}$ at the type section; Winkler Prins, 1968, 1971). The rather thin Barcaliente Formation and the Ricacabiello formation, a condensed succession of grey and purplish shales with manganese nodules, are found in the central part of the basin. These formations contain a fauna of "Culm" type indicating quiet, rather deep waters (Martínez Chacón et al., 1985). In late Bashkirian to early Moscovan times, siliciclastic turbidites grading into shales with limestone bands and occasional reefoid mounds (San Emiliano Formation and equivalents) rest upon or partially replace the Valdeteja Limestone in the west and south (Bowmann, 1985). This pattern of shallowing upwards cycles, ideally from turbidites through shallow marine and paralic deposits to coals and conglomerates (cf. Wagner and Winkler Prins, 2002), is repeated throughout the Moscovian, with the clastic sedimentation shifting from west to east (Bless and Winkler Prins, 1973) and a decreasing marine influence towards the top. Only in the extreme east, in the more stable Picos de Europa area, carbonate deposition was continuous into the Gzhelian (late Stephanian; see Villa and van Ginkel, 1999). The largely marine uppermost Moscovian (upper Myachkovsky) and Kasimovian deposits were laid down in an unconformable basin in eastern León and Palencia (the post-Leonian basin; see Wagner and Winkler Prins, 1985; Wagner et al., 2002). The upper Barruelian and Stephanian B was deposited in a subsequent unconformable basin covering the southern part of the Cantabrian Mountains (post-Asturian basin; see Wagner and Winkler Prins, 1985: 386). This basin, which is almost entirely marine in the area close to the foreland in eastern Asturias, is represented by generally nonmarine coal-bearing successions in a string of coalfields following the arcuate fold belt in northern León, northeastern Palencia, and western Asturias.

The Valdeteja and San Emilano formations and the Cuera Limestones (Bashkirian-Upper Moscovian) are considered in some detail below, because their brachiopod faunas are the best-known faunas of reef affinity from the Carboniferous of the Cantabrian Mountains.

\subsubsection{Valdeteja Formation}

Originally described as the Valdeteja Member of the Escapa Formation (Winkler Prins, 1968), the Valdeteja Limestone was raised to formation rank by Wagner et al. (1971) and its type section was redescribed (Winkler Prins, 1971). It typically consists of a thick (up to $700 \mathrm{~m}$ ) succession of mainly light grey limestones containing algae, locally forming algal mounds and foraminifera and occasional fossiliferous bands with brachiopods, corals, bryozoans, conodonts, etc. These fossiliferous bands may be due to shallowing, which is presumably related to sea-level movements, which are the result of intermittent subsidence of the basin. The formation is exposed in nearly vertical successions in thrust sheets several kilometres apart; these successive sections do not allow a three-dimensional picture 
to be obtained. Both in East-West and North-South directions the formation can be traced for more than a hundred kilometres. The lack of a three-dimensional picture hampers the distinction of the reef structures, which are mainly algal mounds. Extensive dolomitisation and recrystallisation further complicate matters. For example, the importance of coral ghost structures in massive, recrystallised limestone beds cannot be assessed properly (Winkler Prins, 1968: 49). However, it appears obvious that no true coral reefs were present. The carbonate platform of the Valdeteja Formation formed an external rim around a basin, where the mud sedimentation did not keep up with subsidence, a situation comparable to the Viséan reefs in Derbyshire (Wolfenden, 1958). The Valdeteja Formation is of Bashkirian age ranging locally into the earliest Moscovian (Villa et al., 2001).

The massive limestones of the Valdeteja Formation, forming high mountains and deep gorges (hence the old names "caliza de montaña" and "calcaire des cañons"), are not inviting for fossil collecting and for a long time they were considered unfossiliferous (e.g., Martínez Díaz, 1969), though fossils have been found and a rich fauna from the Latores locality in Asturias has been listed by Delépine and Llopis Lladó (1956). The faunas of the Valdeteja Formation are linked to certain horizons (see Winkler Prins, 1968) or occur in pockets, probably related to reef structures (op. cit., loc. 10, north of Cármenes). The brachiopods are by far the most important part of the Valdeteja faunas. Among the microfaunas the foraminifera are most important for dating (Villa, 1982, 1989; Villa et al., 2001), but conodonts (van den Boogaard and Bless, 1985; Méndez and Menéndez Álvarez, 1985) and ostracodes (Bless and Sánchez de Posada, 1973; Sánchez de Posada, 1976; Becker, 1982) also occur (Sánchez de Posada et al., 1996). The latter are of Eifelian type, quite distinct from the Thuringian ones of quiet water deposits (Vegamián, Genicera and Ricacabiello formations). Bryozoans, porifera, anthozoa (de Groot, in Winkler Prins, 1971; Boll, 1985), crinoid ossicles, bivalves, and gastropods are occasionally found; trilobites (Gandl, 1987), ammonoids (Wagner-Gentis, in Martínez Chacón, 1979) and rostroconchs (Babin et al., 1999) are rare. Algae (Rácz, 1964; in Winkler Prins, 1968: Table 3; Eichmüller, 1985) play an important role as mud binders, forming Donezella mounds (Riding, 1978; Bowman, 1979). The first comprehensive list of brachiopods from the Valdeteja Formation was published by Delépine and Llopis Lladó (1956). Descriptions of the Productidina were given by Winkler Prins (1968), while Martínez Chacón (1977, 1979) described the Orthida, Productida, Orthotetida, and Rhynchonellida.

\subsubsection{San Emiliano Formation}

The San Emiliano Formation was originally described by Brouwer and van Ginkel (1964) and formally introduced with a type section by Bowman (1979, 1982, 1985; see also Carballeira et al., 1985; Fernández, 1993). Bowman described the occurrence of Donezella mud mounds in its middle, La Majua, Member and associated oncolithic marls with well-preserved and varied brachiopod faunas. The San Emiliano Formation overlies, and partly replaces laterally, the Valdeteja Formation and is of late Bashkirian to early Moscovian age. Although the deltaic environmental setting is quite different from that of the earlier Valdeteja Formation, its faunas are rather similar but less specialised. 
These mounds were also described from the Cármenes Syncline by Riding (1978), who warned that similar structures could be produced by diagenesis. The deposits described by him are, however, younger and attributed to the Lois-Ciguera Formation by Rácz (1964), who described the algae and mentioned the mounds (see also van Ginkel and Villa, 1996).

The lower, Pinos, Member is practically unfossiliferous. In the La Majua Member algae are found in the limestones (Rácz, 1964), occasionally forming mounds (Bowman, 1982). This member contains well-preserved brachiopod faunas in the marly layers, as well as corals (Kullmann and Rodriguez, 1986), gastropods, bivalves, rostroconchs (Babin et al., 1999), porifera (García-Bellido and Rigby, 2004), trilobites (Romano, 1971; Gandl, 1987), ostracodes (Fernández López and Sánchez de Posada, 1987), crinoids, and echinoids (Winkler Prins, 1968; Sánchez de Posada et al., 1996). Fusulinid foraminifera were helpful in dating the formation (van Ginkel, 1965; Bowman, 1982; van Ginkel and Villa, 1996); its conodont faunas have not yet been described. In the upper, Candemuela, Member the (brachiopod) faunas (Martínez Chacón, in Carballeira et al., 1985) are mainly found as moulds in mudstones. Macrofloral elements have been used for correlation with northwestern Europe (Wagner and Bowman, 1983). Brachiopods were first described by Winkler Prins (1968) and Martínez Chacón (1977,1978a, b, 1979); together they presented a summary of the brachiopod faunas (Martínez Chacón and Winkler Prins, 1986, 2000).

\subsubsection{Cuera Limestones}

The "Calizas del Cuera" (Cuera Limestones), an about 1,000m thick limestone succession of Bashkirian and Moscovian ages, has been informally described by Navarro et al. (1986). It was deposited on a stable carbonate platform adjacent to the Picos de Europa area, but shows a variety of limestone facies with an occasional sandstone intercalation (op. cit.: Fig. 4). A sedimentological study of the type area (della Porta et al., 2004) showed the influence of tectonic subsidence, sea-level fluctuations and high carbonate accumulation rates. The occurrence of the brachiopod Aseptella asturica (Martínez Chacón and Winkler Prins, 1977) in the basal part, just above the Barcaliente Formation, suggests a rather quiet depositonal environment, showing some similarities with those of the San Emiliano Formation (cf. Martínez Chacón and Winkler Prins, 1993). It is mainly in the upper part (upper Moscovian) that Donezella mounds are found and the brachiopod fauna of that part (Martínez Chacón, 1990, 1991) compares better with that of the Valdeteja Formation.

The upper part of the Cuera Limestones, especially at the locality Hontoria, has rich faunas: bryozoans, corals (de Groot in Martínez Chacón, 1979; Rodriguez and Ramírez, 1987), bivalves, gastropods, crinoids, and ostracodes (Sánchez de Posada and Bless, 1999; Sánchez de Posada and Fohrer, 2001). Rich fusulinid faunas were found as well (Villa Otero, 1995), whereas conodonts are rare. Both below and above the limestone at Hontoria, miospores were found indicating a Westphalian D age (García Bartolomé et al., 2003). The brachiopods were described by Martínez Chacón (1975, 1977, 1979, 1990, 1991; Martínez Chacón and Bahamonde, in press; see also Sánchez de Posada et al., 1993). 


\section{Discussion of the Brachiopod Faunas from the Cantabrian Mountains}

The analysis of the brachiopod faunas associated with these reefs is here confined to examples from the Bashkirian and Moscovian of Asturias and León, since these brachiopod faunas are currently the best known. The brachiopod faunas from the Cuera Limestones have been largely described (Martínez Chacón, 1990, 1991; Martínez Chacón and Bahamonde, in press), but complete descriptions of the other faunas, especially those from the Valdeteja Formation, are still outstanding. The information on the brachiopod faunas is summarised in Table 1. A short discussion of the brachiopod reef assemblages from the Valdeteja Formation and Cuera imestones was given by Martínez Chacón (in Sánchez de Posada et al., 2002).

The inarticulate brachiopods are rare in the reef faunas and are not considered here. The Rafinesquinidae, represented in the Viséan Cracoe reef environment of Yorkshire by Leptagonia, became extinct before the end of the Mississippian. Chonetidina are not specific for a reefoid environment with agitated water, and indeed more commonly associated with a muddy sea floor. The occasional specimens probably lived in sheltered areas. On the other hand, many of the Productidina and Strophalosiidina preferred agitated water (e.g., Fluctuaria undata; see Fig. 2 (6)) and some forms are considered characteristic of a reef environment (e.g., Mundy and Brunton, 1985; Brunton and Mundy, 1986, 1988; Brunton et al., 1994). Examples, also found in the Cantabrian Mountains, are Productina, Eomarginifera, Heteralosia, and possibly Limbifera (figured as Institina? sp. by Martínez Chacón and Winkler Prins, 1993; see Fig. 2 (2)); Plicatiferina had presumably a similar lifestyle as Plicatifera and thus may be considered another example (see specimen with attachment ring of Fig. 2 (9)). Proboscidella proboscidea was found in a reef limestone assigned to the Perapertú Formation near Verbios (Palencia), which is early Moscovian in age (Fig. 2 (7)). The "reef-building" Richthofenioidea (Flajs et al., 1996) are extremely rare in the Cantabrian Mountains; in fact, only one specimen of Zalvera sp. has been described so far from an upper Moscovian limestone in Palencia (Brunton, 1996; Fig. 2 (5)). Parmephrix, a characteristic element of the Viséan reefs in Derbyshire (Brunton et al., 1994), has only been found questionably in quiet water faunas of the Tournaisian black shales of the Vegamián Formation: Parmephrix? aprathensis (cf. Martínez Chacón and Winkler Prins, 1993). These specimens probably drifted in attached to goniatites as suggested by their ornamentation. A recent revision of the brachiopods from the Valdeteja Formation (see Martínez Chacón and Winkler Prins, 2006a) and notably of the locality of Latores (Martínez Chacón and Winkler Prins, 2006b) has shown the presence of rare specimens related to typical reef-related taxa from the Viséan of the British Isles (Mundy and Brunton, 1985; Brunton and Mundy, 1988), such as Stipulina? sp., Institina? sp., and Retroplexus? sp. (Fig. $2(4,5))$. The Incisiini gen. et sp. nov. (the genus has been referred to with the nomen nudum "Regrantia", e.g., Martínez Chacón and Winkler Prins, 1993) has occasionally been found in the Valdeteja and San Emiliano formations and thus is the oldest known member of the tribe. It does not seem to be particularly adapted to a reef environment, lying anchored in the mud with its spines. 


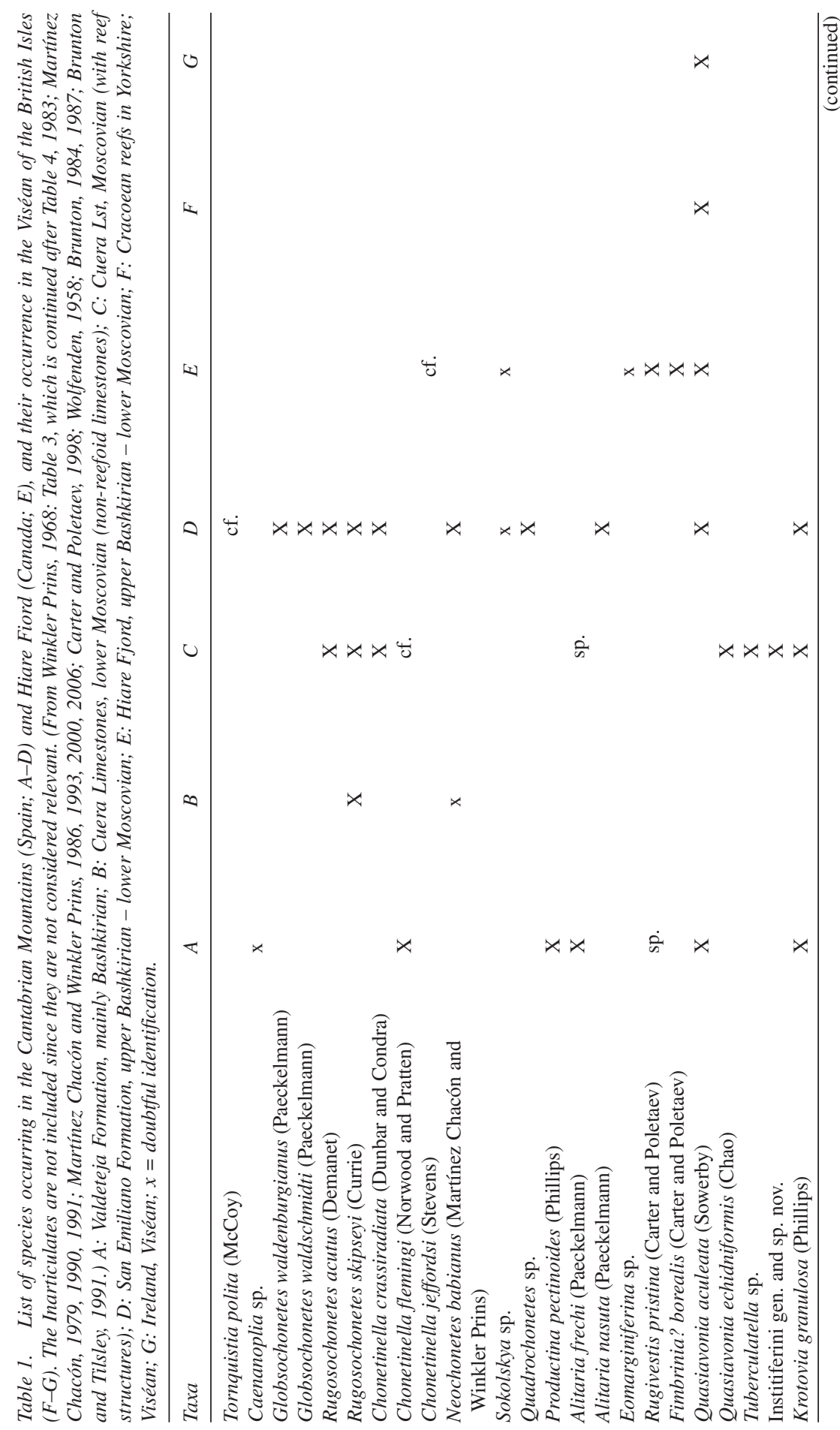




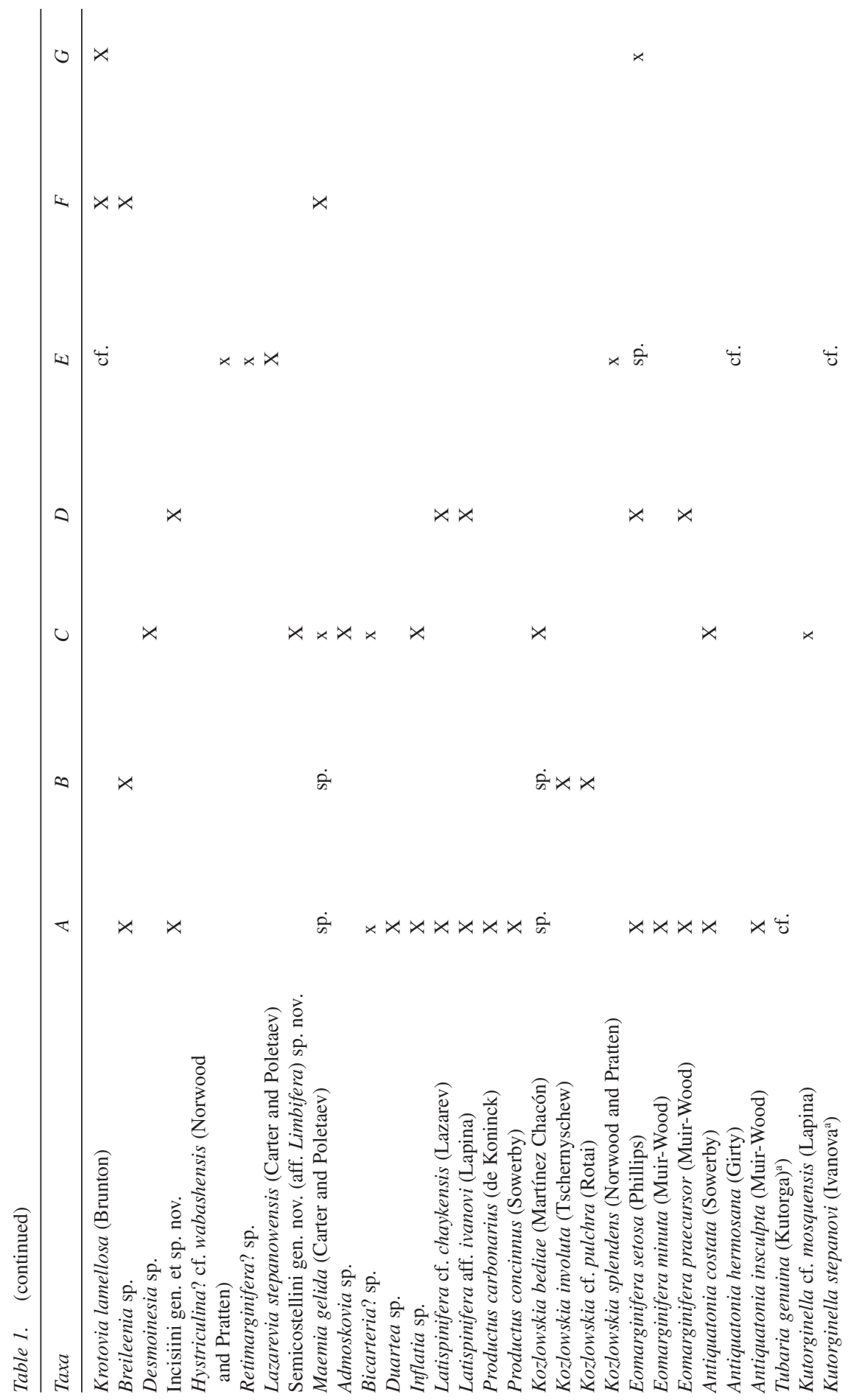




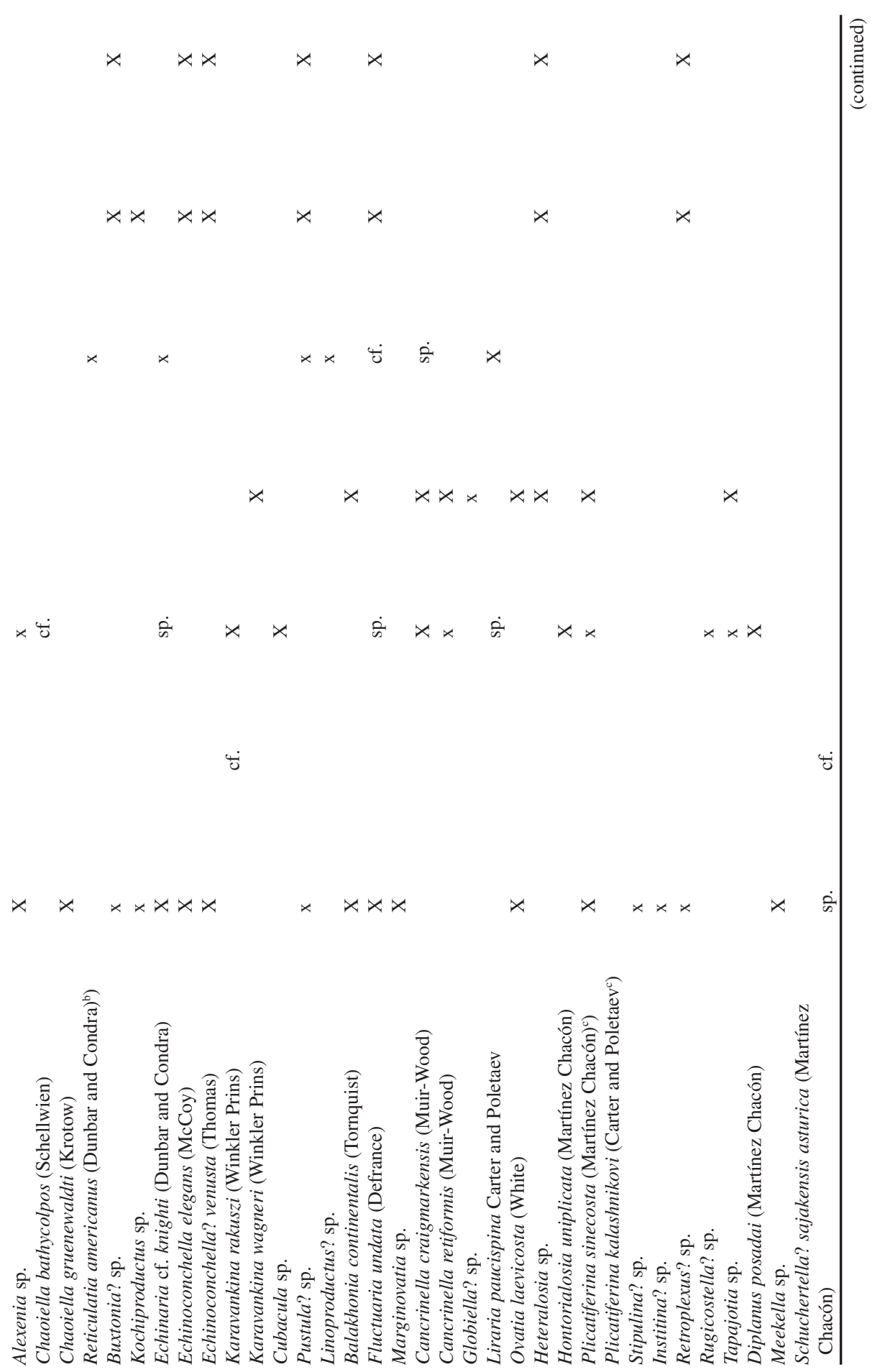




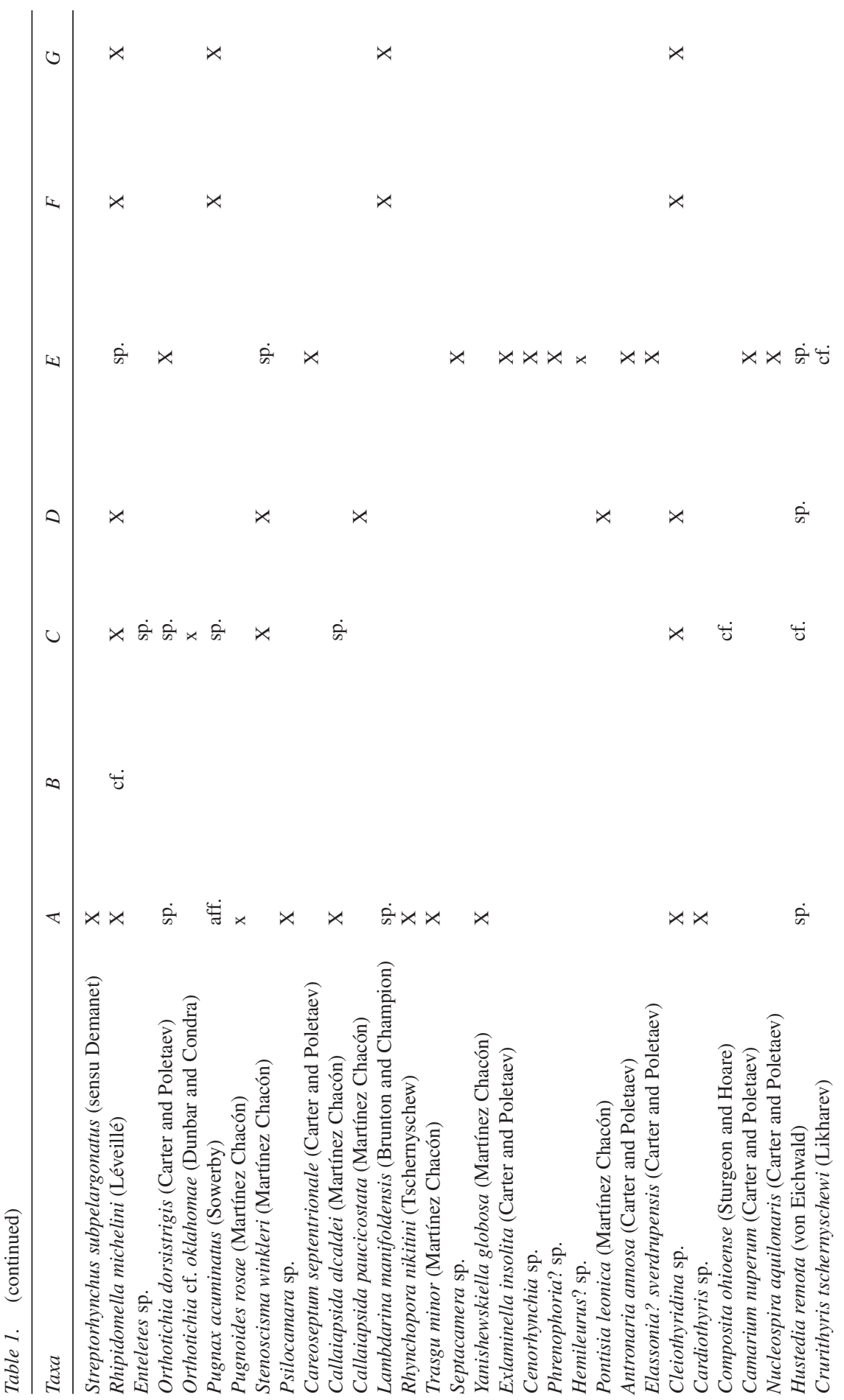


$x \times$

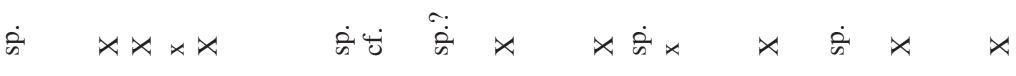

$\ddot{\circlearrowleft} \ddot{\circlearrowleft}$

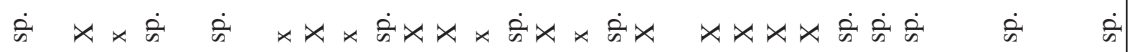

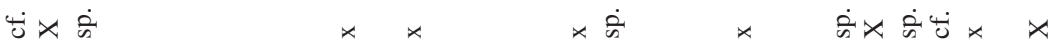

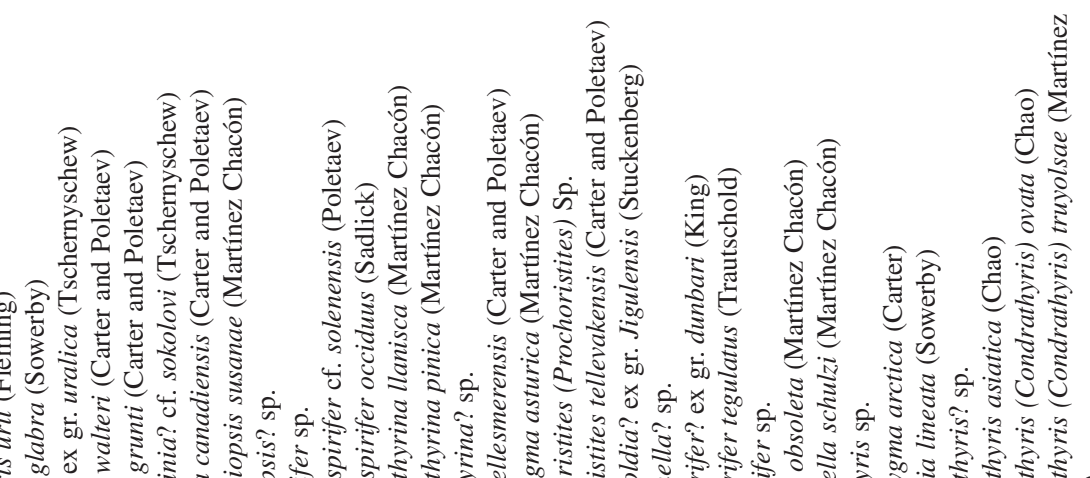

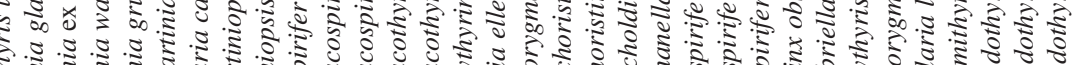

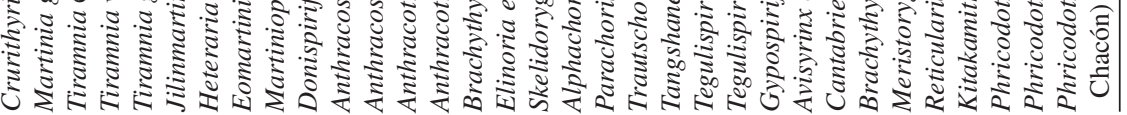




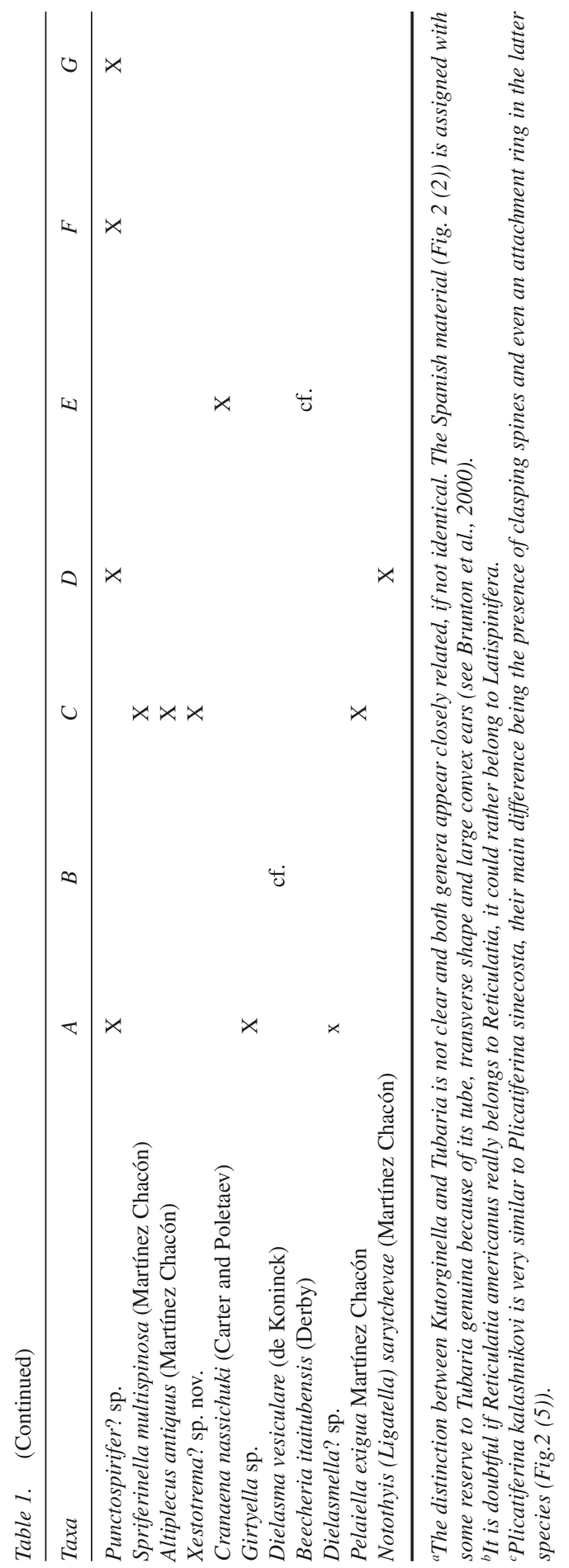


Some Orthida, such as Schizophoria, are common in a reef environment but also occur in other deposits. The same holds true for some Orthotetidina, like Diplanus and Streptorhynchus with their large interareas, and for the Stenoscismatoidea with forms like Stenoscisma and Callaiapsida. The importance of differences in internal structures in many small, attached forms for their way of life and for their relations is difficult to judge. Lambdarina was a small rhynchonellid that lived sheltered in the reef (e.g., Brunton and Champion, 1974; Bassett and Bryant, 1993), possibly attached to algae or bryozoans. Rhynchopora also appears to be characteristic of reef environments in Pennsylvanian and Permian times. This genus may have been derived from the Viséan Tretorhynchia. Several Athyrididina species lived on the reefs but not exclusively so, since they were not particularly adapted to them. The same holds true for many representatives of the Spiriferida and Spiriferinida, but some forms were particularly well adapted to agitated water through their relatively large interareas (Cantabriella, Avisyrinx, Altiplecus) and large size (Trautscholdia), although Cantabriella and Trautscholdia are also found in mudstones. The Terebratulida have no apparent adaptations to life on a reef, other than their pedicle attachment, and the Spanish material has not been studied in sufficient detail to allow consideration here.

\section{Relation with Other Areas}

As an example of Viséan reefs from Northwest Europe the Craven reef belt of North Yorkshire (Table 2) is chosen for comparison, since the brachiopod faunas are well known through the summary by Wolfenden (1958) and the work of Brunton and others (e.g., Brunton and Mundy, 1988; Brunton and Tilsley, 1991; Brunton et al., 1994). Data from Ireland (Brunton, 1966, 1968, 1984, 1987; Harper and Jeffrey, 1996) only marginally modify the picture. They have many genera and species in common with the Valdeteja Formation, which at first glance make the impression of Viséan faunas. Only some Moscovian elements (e.g., Chaoiella, Reticulatia, and Rhynchopora) and the absence of some of the more typical Mississippian forms, such as Leptagonia and Gigantoproductus, suggest a younger, i.e., Bashkirian, age (Winkler Prins, 1968), which has been corroborated by fusulinid evidence (Villa, 1982).

Although it is less apparent when considering only the reef-related faunas, there is a close relationship between the Carboniferous brachiopod faunas from the Cantabrian Mountains and those from the Carboniferous-Permian of the Carnic Alps and the Karavanke Mountains in Slovenia with genera such as Isogramma and Eolyttonia (e.g., Ramovš, 1971; Winkler Prins, 1983; Martínez Chacón and Winkler Prins, 1993), and to a lesser extent also with the Bükk Mountains (Gulyás-Kis, 2004). Also other faunal elements, such as the corals (Rodriguez et al., 1986; Kullmann and Rodríguez, 1994) and ostracods (Sánchez de Posada and Fohrer, 2001), show a close relationship with the Carnic Alps. The connections extended along the Palaeotethys as far east as Thailand, though no 


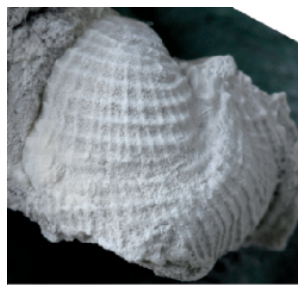

1A

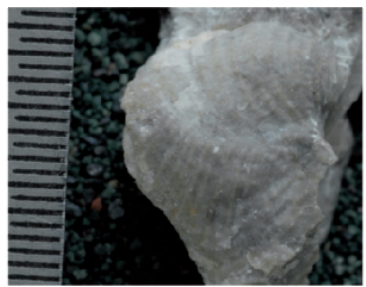

1B

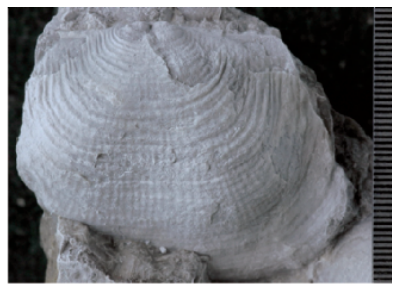

2

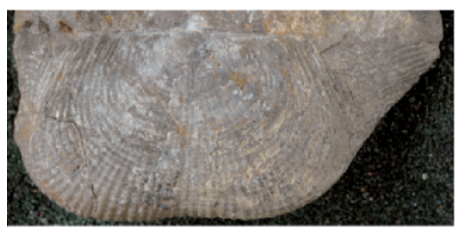

$3 \mathrm{~A}$

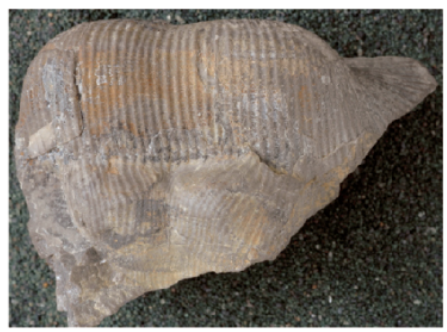

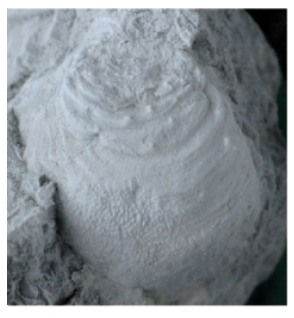

4

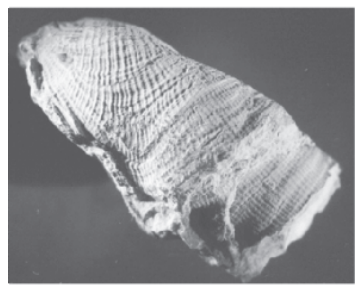

$7 \mathrm{~A}$

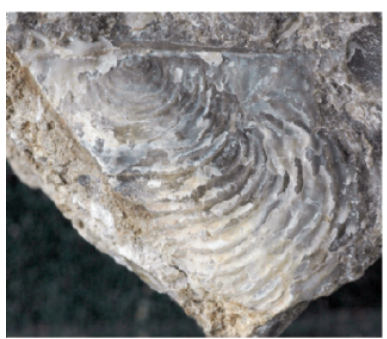

8

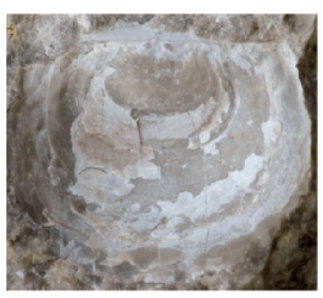

5

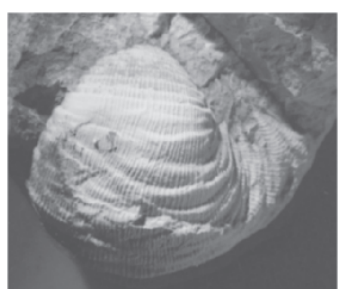

6
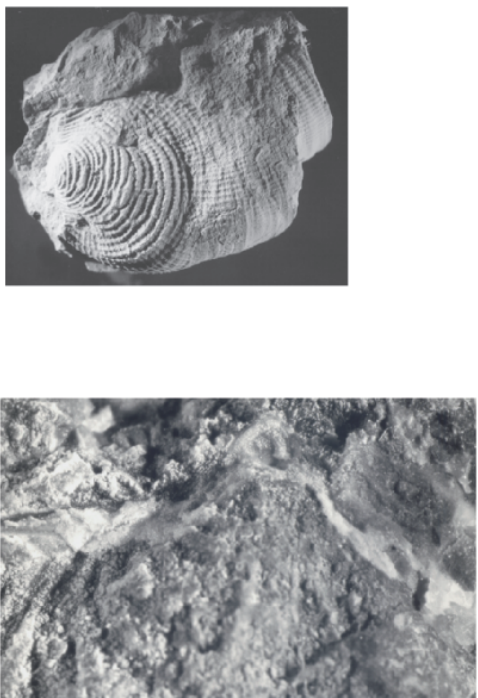

Fig. 2 
typical reef forms were found there (e.g., Comuquia, Tuberculatella, Incisiini; cf. Winkler Prins, 1983).

The Urals were a less closely related area during the Carboniferous but the late Pennsylvanian and early Permian show some specialised forms belonging to genera known from earlier deposits in the Cantabrian Mountains, e.g., Rugivestis kutorgae (Tschernyschew, 1902) and Avisyrinx? expansa (Tschernyschew, 1902). The Spitsbergen faunas are similar to those from the Urals, but typical reef forms are seemingly absent. The Permian brachiopods from Greenland appear to be rather distinct, probably due to palaeoecological and climatic differences.

Surprisingly, the brachiopod fauna from the upper Bashkirian or lower Moscovian Hare Fiord Formation of Ellesmere Island (Canadian Arctic Archipelago) (Carter and Poletaev, 1998) proved quite similar to the Spanish faunas, particularly from the Valdeteja Formation. Excluding the terebratulids, Hare Fiord has 28 of its 42 genera in common with the Cantabrian Mountains, which is more than with the Urals or with Texas (see Table 2). The similarity is even greater when one considers such closely related forms, as Tubaria and Kutorginella (see Table 1; Fig. 2 (3)), Pontisia and Antronaria and Eomartiniopsis and Heteraria. The fact that they derived in part from bryozoan reef mounds (Carter and Poletaev, 1998: 106) is a partial explanation. One wonders, however, whether the connection with the Canadian Arctic was through the Arctic, Spitsbergen and the Urals, or whether there existed another seaway along eastern North America, as suggested by Bless and Winkler Prins (1972). Unfortunately, the Pennsylvanian brachiopod faunas from the Appalachians are practically undescribed.

Fig. 2 Some brachiopods from the Cantabrian Mountains characteristic of reef facies: (1) Rugivestis sp., pedicle valve (RGM 288956); from the Valdeteja Formation north of Cármenes (León; Winkler Prins, 1968, loc. 10); A: anterior view, ×4; B: lateral view, ×4; (2) Limbifera? sp. brachial valve (RGM 290805); from the upper part of the Valdeteja Formation at Latores (Asturias; loc. WP101); dorsal view, ×1.6; (3) Tubaria cf. genuina (Kutorga, 1844), brachial valve (RGM 288953); from the local equivalent of the Valdeteja Formation at $1 \mathrm{~km}$ East of Santa María de Nava (Palencia; loc. Wa21); A: dorsal view, $\times 1$; B: anterior view, $\times 1$; (4) Institina? sp., pedicle valve (RGM 288957); from the upper part of the Valdeteja Formation at Latores (Asturias; loc. WP101); lateral view, ×3; (5) Institina? sp., brachial valve (RGM 288958); from the upper part of the Valdeteja Formation at Latores (Asturias; loc. WP101); dorsal view, $\times 3.5$; (6) Fluctuaria undata (Defrance, 1826), pedicle valve (RGM 142545); from the Valdeteja Formation north of Vegacervera (León; loc. Wa925); posterior view, $\times 1$; (7) Proboscidella proboscidea (de Verneuil, 1840) pedicle valve (RGM 142805); from a reef limestone of the Perapertú Formation westnorthwest of Verbios (Palencia; loc. dG511); A: lateral view, ×2; B: posterior view, ×2; (8) Plicatiferina sinecosta (Martínez Chacón, 1979) (RGM 290597); brachial valve and fragment of pedicle valve with spines from its type locality, the upper part of the Valdeteja Formation at Latores (Asturias); ventral view, $\times 2$; (9) Plicatiferina sinecosta (Martínez Chacón, 1979) (RGM 288955); pedicle valve from its type locality, the upper part of the Valdeteja Formation at Latores (Asturias); umbonal view, note attachment ring, $\times 12$. 
Table 2. List of genera occurring in the faunas from the Cantabrian Mountains described above (Spain: $C M)$, Hiare Fiord $(H F)$, and in the Viséan of the British Isles $(C)$; and their occurrence in other areas; D: Alps (mainly Permian); E: Urals (Carboniferous-Permian); F: Spitsbergen (PennsylvanianPermian); G: Texas (Permian); $x=$ doubtful occurrence (counted as half). The Inarticulates and Terebratulida are not included since they are not considered relevant. Due to a lack of modern revisions are the numbers in columns D-F minima. For literature see Table 1 and the References.

\begin{tabular}{|c|c|c|c|c|c|c|c|}
\hline Genus & $C M$ & $H F$ & $C$ & $D$ & $E$ & $F$ & $G$ \\
\hline Leptagonia & & & $\mathrm{X}$ & & & & \\
\hline Tornquistia & $X$ & & & & & $X$ & \\
\hline Caenanoplia & $\mathrm{x}$ & & & & & & \\
\hline Globosochonetes & $\mathrm{X}$ & & $\mathrm{X}$ & & & & \\
\hline Rugosochonetes & $\mathrm{X}$ & & $\mathrm{X}$ & & & & \\
\hline Chonetinella & $\mathrm{X}$ & $\mathrm{X}$ & & & $\mathrm{X}$ & $X$ & $\mathrm{X}$ \\
\hline Neochonetes & $\mathrm{X}$ & & & & $\mathrm{X}$ & $\mathrm{X}$ & $\mathrm{X}$ \\
\hline Sokolskya & $\mathrm{x}$ & $\mathrm{x}$ & & & & & \\
\hline Megachonetes & & & $\mathrm{X}$ & & & & \\
\hline Plicochonetes & $\mathrm{x}$ & & $\mathrm{X}$ & & & & \\
\hline Quadrochonetes & $\mathrm{x}$ & & & & & & $\mathrm{X}$ \\
\hline Productina & $X$ & & $\mathrm{X}$ & & & & \\
\hline Argentiproductus & & & $\mathrm{X}$ & & & & \\
\hline Alitaria & $X$ & & $\mathrm{X}$ & & & & \\
\hline Eomarginiferina & & $\mathrm{x}$ & $\mathrm{X}$ & & & & \\
\hline Rugivestis & $\mathrm{X}$ & $\mathrm{X}$ & & & $\mathrm{X}$ & & $\mathrm{x}$ \\
\hline Overtonia & & & $\mathrm{X}$ & & & & \\
\hline Fimbrinia & & $\mathrm{x}$ & $\mathrm{X}$ & & $\mathrm{X}$ & & $\mathrm{X}$ \\
\hline Avonia & & & $\mathrm{X}$ & & $\mathrm{X}$ & & \\
\hline Quasiavonia & $X$ & & $\mathrm{X}$ & $\mathrm{x}$ & & & \\
\hline Tuberculatella & $X$ & & & & & & \\
\hline Institifera & $\mathrm{x}$ & & $\mathrm{X}$ & & & & \\
\hline Krotovia & $\mathrm{X}$ & $X$ & $\mathrm{X}$ & $\mathrm{X}$ & $\mathrm{X}$ & $\mathrm{X}$ & \\
\hline Breileenia & $\mathrm{X}$ & & $\mathrm{X}$ & & & & \\
\hline Desmoinesia & $\mathrm{X}$ & & & & & & \\
\hline Incisiini gen. nov. & $\mathrm{X}$ & & & & & & \\
\hline Hystriculina & & $\mathrm{x}$ & & $\mathrm{x}$ & & & \\
\hline Retimarginifera & & $\mathrm{x}$ & & & & & \\
\hline Plicatifera & & & $\mathrm{X}$ & & & & \\
\hline Lazarevia & & $\mathrm{X}$ & & & & & \\
\hline Semicostella & & & $\mathrm{x}$ & & $\mathrm{X}$ & & \\
\hline Acanthoplecta & & & $\mathrm{X}$ & & & & \\
\hline Admodorugosus & & & $\mathrm{X}$ & & & & \\
\hline Geniculifera & & & $\mathrm{X}$ & & & & \\
\hline Carringtonia & & & $\mathrm{X}$ & & & & \\
\hline Cinctifera & & & $\mathrm{X}$ & & & & \\
\hline Limbifera & $\mathrm{x}$ & & $\mathrm{X}$ & & & & \\
\hline Maemia & $X$ & $X$ & & & & & \\
\hline Admoskovia & $\mathrm{X}$ & & & & & & \\
\hline Bicarteria & $\mathrm{x}$ & & & & & $\mathrm{X}$ & \\
\hline Duuartea & $\mathrm{X}$ & & & & & $\mathrm{x}$ & \\
\hline Inflatia & $\mathrm{X}$ & & $\mathrm{X}$ & & & & \\
\hline Latispinifera & $X$ & $\mathrm{x}$ & & & & $\mathrm{X}$ & \\
\hline Tenaspinus & & & $\mathrm{X}$ & & & & \\
\hline Productus & $\mathrm{X}$ & & $\mathrm{X}$ & & $\mathrm{X}$ & & \\
\hline Kozlowskia & $X$ & $\mathrm{x}$ & & $\mathrm{x}$ & $\mathrm{X}$ & $\mathrm{x}$ & $\mathrm{X}$ \\
\hline Eomarginifera & $\mathrm{X}$ & $\mathrm{X}$ & $\mathrm{X}$ & & & & \\
\hline Antiquatonia & $\mathrm{X}$ & $\mathrm{X}$ & $\mathrm{X}$ & & $\mathrm{X}$ & & $\mathrm{X}$ \\
\hline
\end{tabular}


Table 2. (Continued)

\begin{tabular}{|c|c|c|c|c|c|c|c|}
\hline Genus & $C M$ & $H F$ & $C$ & $D$ & $E$ & $F$ & $G$ \\
\hline Tubaria & $\mathrm{X}$ & $\mathrm{x}$ & & & $\mathrm{X}$ & $\mathrm{X}$ & $\mathrm{x}$ \\
\hline Kutorginella & $\mathrm{X}$ & $\mathrm{X}$ & & & $\mathrm{X}$ & & \\
\hline Alexenia & $\mathrm{X}$ & & & & $\mathrm{X}$ & & \\
\hline Dictyoclostus & & & $\mathrm{X}$ & & & $\mathrm{x}$ & \\
\hline Chaoiella & $\mathrm{X}$ & & & $\mathrm{x}$ & $\mathrm{X}$ & $\mathrm{X}$ & \\
\hline Pugilis & $\mathrm{x}$ & & $\mathrm{X}$ & & & & \\
\hline Reticulatia & & $\mathrm{x}$ & & & $\mathrm{X}$ & $\mathrm{X}$ & $\mathrm{X}$ \\
\hline Buxtonia & $\mathrm{x}$ & & $X$ & & $\mathrm{X}$ & $\mathrm{X}$ & \\
\hline Kochiproductus & $\mathrm{x}$ & & $\mathrm{X}$ & & $\mathrm{X}$ & & $\mathrm{X}$ \\
\hline Marginicinctus & & & $\mathrm{X}$ & & & & \\
\hline Echinoconchus & & & $X$ & & & $\mathrm{X}$ & \\
\hline Echinaria & $\mathrm{X}$ & $\mathrm{x}$ & & & $\mathrm{X}$ & $\mathrm{x}$ & $\mathrm{X}$ \\
\hline Echinoconchella & $\mathrm{X}$ & & $\mathrm{X}$ & & & $\mathrm{X}$ & \\
\hline Karavankina & $\mathrm{X}$ & & & $\mathrm{X}$ & $\mathrm{X}$ & & \\
\hline Cubacula & $\mathrm{X}$ & & & & $\mathrm{X}$ & & \\
\hline Pustula & $\mathrm{x}$ & $\mathrm{x}$ & $\mathrm{X}$ & & & $\mathrm{X}$ & \\
\hline Stegacanthia & & & $\mathrm{X}$ & & & & \\
\hline Linoproductus & $\mathrm{x}$ & $\mathrm{x}$ & $\mathrm{x}$ & $\mathrm{x}$ & $\mathrm{X}$ & $\mathrm{X}$ & $\mathrm{X}$ \\
\hline Balakhonia & $\mathrm{X}$ & & $\mathrm{X}$ & & $\mathrm{x}$ & & \\
\hline Fluctuaria & $\mathrm{X}$ & $\mathrm{X}$ & $\mathrm{X}$ & & $X$ & & \\
\hline Marginovatia & $\mathrm{X}$ & & & & & & \\
\hline Cancrinella & $\mathrm{X}$ & $\mathrm{X}$ & & $\mathrm{x}$ & $\mathrm{X}$ & $\mathrm{X}$ & $\mathrm{X}$ \\
\hline Globiella? & $\mathrm{x}$ & & & & & & \\
\hline Linoprotonia & & & $\mathrm{X}$ & & & & \\
\hline Liraria & $\mathrm{X}$ & $\mathrm{X}$ & & & & & \\
\hline Ovatia & $\mathrm{X}$ & & $\mathrm{X}$ & & & $\mathrm{X}$ & \\
\hline Undaria & & & $\mathrm{X}$ & & & & \\
\hline Vitiliproductus & & & $\mathrm{X}$ & & & & \\
\hline Gigantoproductus & & & $\mathrm{X}$ & & $\mathrm{X}$ & & \\
\hline Semiplanus & & & $\mathrm{X}$ & & & & \\
\hline Latiproductus & & & $\mathrm{X}$ & & & & \\
\hline Semiplanella & & & $\mathrm{X}$ & $\mathrm{X}$ & & & \\
\hline Striatifera & & & $\mathrm{X}$ & & $\mathrm{X}$ & $\mathrm{x}$ & $\mathrm{X}$ \\
\hline Proboscidella & $\mathrm{X}$ & & $\mathrm{X}$ & & & & \\
\hline Heteralosia & $\mathrm{X}$ & & $\mathrm{X}$ & & & & $\mathrm{X}$ \\
\hline Dasyalosia & & & $\mathrm{X}$ & & & $\mathrm{X}$ & \\
\hline Crossalosia & & & $\mathrm{X}$ & & & & \\
\hline Hontorialosia & $\mathrm{X}$ & & & & & & \\
\hline Pamephrix & & & $\mathrm{X}$ & & & & \\
\hline Semenewia & & & $X$ & & & & \\
\hline Plicatiferina & $\mathrm{X}$ & $\mathrm{X}$ & & & $\mathrm{X}$ & & \\
\hline Stipulina & $\mathrm{x}$ & & $\mathrm{X}$ & & & & \\
\hline Institina & $\mathrm{x}$ & & $\mathrm{X}$ & & & & \\
\hline Retroplexus & $\mathrm{x}$ & & $\mathrm{X}$ & & & & \\
\hline Rugicostella & $\mathrm{x}$ & & $\mathrm{X}$ & & & & \\
\hline Sinuatella & & & $\mathrm{X}$ & & & $\mathrm{X}$ & \\
\hline Apsocalyma & & & $\mathrm{X}$ & & & & \\
\hline Brochocarina & & & $\mathrm{X}$ & & & & \\
\hline Tapajotia & $\mathrm{X}$ & & & & & & \\
\hline Meekella & $\mathrm{X}$ & & & & $\mathrm{X}$ & $\mathrm{X}$ & $\mathrm{X}$ \\
\hline Schellwienella & & & $\mathrm{X}$ & & & $\mathrm{X}$ & \\
\hline Diplanus & $\mathrm{X}$ & & & & & & $\mathrm{X}$ \\
\hline Schuchertella & $\mathrm{x}$ & & $\mathrm{X}$ & & & & $\mathrm{x}$ \\
\hline Serratocrista & & & $\mathrm{X}$ & & & & \\
\hline Streptorhynchus & $\mathrm{X}$ & & $\mathrm{X}$ & $\mathrm{X}$ & $\mathrm{X}$ & $\mathrm{X}$ & \\
\hline
\end{tabular}


Table 2. (continued)

\begin{tabular}{|c|c|c|c|c|c|c|c|}
\hline Genus & $C M$ & $H F$ & C & $D$ & $E$ & $F$ & $G$ \\
\hline Rhipidomella & $X$ & $\mathrm{X}$ & $\mathrm{X}$ & $\mathrm{x}$ & $\mathrm{X}$ & $\mathrm{X}$ & $\mathrm{X}$ \\
\hline Enteletes & $\mathrm{X}$ & & & $\mathrm{X}$ & $\mathrm{X}$ & & $\mathrm{X}$ \\
\hline Schizophoria & $\mathrm{x}$ & & $\mathrm{X}$ & & $\mathrm{X}$ & & \\
\hline Aulacophoria & & & $\mathrm{X}$ & & $\mathrm{X}$ & & \\
\hline Pocockia & & & $\mathrm{X}$ & & & & \\
\hline Orthotichia & $\mathrm{X}$ & $\mathrm{X}$ & & & $\mathrm{X}$ & $\mathrm{X}$ & $\mathrm{X}$ \\
\hline Pugnax & $X$ & & $\mathrm{X}$ & & & & \\
\hline Pleuropugnoides & & & $\mathrm{X}$ & & & & \\
\hline Propriopugnus & & & $\mathrm{X}$ & & & & \\
\hline Pugnoides & $X$ & & $\mathrm{X}$ & & & & \\
\hline Stenoscisma & $\mathrm{X}$ & $\mathrm{X}$ & $\mathrm{X}$ & $\mathrm{x}$ & $\mathrm{X}$ & & $\mathrm{X}$ \\
\hline Coledium & & & $\mathrm{x}$ & $\mathrm{X}$ & & & \\
\hline Psilocamara & $\mathrm{X}$ & & & & & & $\mathrm{X}$ \\
\hline Careoseptum & & $\mathrm{X}$ & & & & & \\
\hline Callaiapsida & $\mathrm{X}$ & & & & & & \\
\hline Lambdarina & $\mathrm{X}$ & & $\mathrm{X}$ & & & & \\
\hline Rhynchopora & $\mathrm{X}$ & & & $\mathrm{x}$ & $\mathrm{X}$ & $\mathrm{X}$ & $\mathrm{X}$ \\
\hline Tretorhynchia & & & $\mathrm{X}$ & & & & \\
\hline Trasgu & $\mathrm{X}$ & & & & & & \\
\hline Septacamera & & $\mathrm{X}$ & & & & & \\
\hline Yanishewskiella & $\mathrm{X}$ & & & & $\mathrm{X}$ & & \\
\hline Exlaminella & & $\mathrm{X}$ & & & & & \\
\hline Cenorhynchia & & $\mathrm{X}$ & & & & & \\
\hline Phrenophoria & & $\mathrm{x}$ & & & & & \\
\hline Hemileurus & & $\mathrm{x}$ & & & & & \\
\hline Pontisia & $\mathrm{X}$ & & & & & & $\mathrm{X}$ \\
\hline Antronaria & & $\mathrm{X}$ & & & & & \\
\hline Elassonia & & $\mathrm{x}$ & & & & & \\
\hline Actinoconchus & & & $\mathrm{X}$ & & & & \\
\hline Athyris & & & $\mathrm{X}$ & & & & \\
\hline Lamellosathyris & & & $\mathrm{X}$ & & & & \\
\hline Cleiothyridina & $\mathrm{X}$ & & $\mathrm{X}$ & $\mathrm{x}$ & $\mathrm{X}$ & $\mathrm{X}$ & $\mathrm{X}$ \\
\hline Cardiothyris & $\mathrm{X}$ & & & & & & \\
\hline Composita & $\mathrm{X}$ & & $\mathrm{X}$ & & $\mathrm{X}$ & $\mathrm{X}$ & $\mathrm{X}$ \\
\hline Camarium & & $\mathrm{X}$ & & & & & \\
\hline Nucleospira & & $\mathrm{X}$ & $\mathrm{X}$ & & & & $\mathrm{X}$ \\
\hline Hustedia & $\mathrm{X}$ & $\mathrm{X}$ & $\mathrm{X}$ & $\mathrm{X}$ & $\mathrm{X}$ & $\mathrm{X}$ & $\mathrm{X}$ \\
\hline Plectospira & & & $\mathrm{x}$ & & & & \\
\hline Crurithyris & $\mathrm{X}$ & $X$ & $\mathrm{X}$ & & $\mathrm{X}$ & $\mathrm{X}$ & $\mathrm{X}$ \\
\hline Martinia & $\mathrm{X}$ & & $\mathrm{X}$ & $\mathrm{X}$ & $\mathrm{X}$ & $\mathrm{X}$ & $\mathrm{X}$ \\
\hline Tiramnia & $\mathrm{X}$ & $\mathrm{X}$ & & & $\mathrm{X}$ & & \\
\hline Jilinmartinia & & $\mathrm{x}$ & & & $\mathrm{X}$ & & \\
\hline Heteraria & $\mathrm{X}$ & $\mathrm{x}$ & & & & & \\
\hline Merospirifer & & & $\mathrm{X}$ & & & & \\
\hline Eomartiniopsis & $\mathrm{X}$ & & & & & & \\
\hline Martiniopsis & $\mathrm{x}$ & & & & $\mathrm{X}$ & & \\
\hline Spirifer & & & $\mathrm{X}$ & & & & \\
\hline Donispirifer & $\mathrm{x}$ & & & & $\mathrm{X}$ & & \\
\hline Anthracospirifer & $X$ & $\mathrm{x}$ & & & & & \\
\hline Podtsheremia & & & $\mathrm{X}$ & & & & \\
\hline Angiospirifer & & & $\mathrm{X}$ & & & & \\
\hline Anthracothyrina & $\mathrm{X}$ & $\mathrm{x}$ & $\mathrm{X}$ & & & & \\
\hline Brachythyrina & $\mathrm{x}$ & $\mathrm{x}$ & & $\mathrm{X}$ & $\mathrm{X}$ & $\mathrm{X}$ & \\
\hline
\end{tabular}


Table 2. (continued)

\begin{tabular}{|c|c|c|c|c|c|c|c|}
\hline Genus & $C M$ & $H F$ & $C$ & $D$ & $E$ & $F$ & $G$ \\
\hline Elinoria & & $\mathrm{X}$ & & & & & \\
\hline Choristites & $\mathrm{x}$ & $\mathrm{x}$ & & & $\mathrm{X}$ & $\mathrm{X}$ & \\
\hline Alphachoristites (Prochoristites) & $\mathrm{X}$ & & & & $\mathrm{X}$ & & \\
\hline Parachoristites & $\mathrm{X}$ & $\mathrm{X}$ & & & $\mathrm{X}$ & & \\
\hline Trautscholdia & $\mathrm{x}$ & $\mathrm{x}$ & & $\mathrm{X}$ & $\mathrm{X}$ & & $\mathrm{X}$ \\
\hline Tangshanella & & $\mathrm{x}$ & & & & & \\
\hline Tegulispirifer & $\mathrm{X}$ & & & $\mathrm{X}$ & $\mathrm{X}$ & $\mathrm{X}$ & \\
\hline Gypospirifer & $\mathrm{X}$ & $\mathrm{x}$ & & & & & \\
\hline Avisyrinx & $\mathrm{X}$ & & & & $\mathrm{X}$ & & \\
\hline Cantabriella & $\mathrm{X}$ & $\mathrm{X}$ & & $\mathrm{x}$ & & & \\
\hline Fusella & & & $\mathrm{X}$ & & & & \\
\hline Brachythyris & $X$ & & $\mathrm{X}$ & $\mathrm{x}$ & $\mathrm{X}$ & & \\
\hline Meristorygma & $X$ & $X$ & & & & & \\
\hline Skelidorygma & $\mathrm{X}$ & & $\mathrm{X}$ & & & & \\
\hline Tylothyris & & & $\mathrm{X}$ & & & & \\
\hline Reticularia & $\mathrm{x}$ & & $\mathrm{X}$ & & $\mathrm{x}$ & $\mathrm{X}$ & \\
\hline Georgethyris & & & $\mathrm{X}$ & & & & \\
\hline Kitakamithyris & $\mathrm{x}$ & & & & & & \\
\hline Phricodothyris & $\mathrm{X}$ & $X$ & $\mathrm{x}$ & & $\mathrm{x}$ & & $\mathrm{X}$ \\
\hline Phricodothyris (Condrathyris) & $\mathrm{X}$ & & & & & & \\
\hline Cyrtina & & & $\mathrm{X}$ & & & & \\
\hline Davidsonina & & & $\mathrm{X}$ & & $\mathrm{X}$ & & \\
\hline Syringothyris & & & $\mathrm{X}$ & & & & \\
\hline Asyrinxia & & & $\mathrm{X}$ & & & & \\
\hline Punctospirifer & $\mathrm{x}$ & & $\mathrm{X}$ & & $\mathrm{X}$ & $\mathrm{X}$ & \\
\hline Altiplecus & $\mathrm{X}$ & & & & & & $\mathrm{X}$ \\
\hline Spriferellina & $X$ & & $\mathrm{X}$ & & & & $\mathrm{X}$ \\
\hline Crenispirifer & $\mathrm{X}$ & & & & & & \\
\hline Xestotrema & $\mathrm{x}$ & & & & & & \\
\hline Minithyra & & & $\mathrm{X}$ & & & & \\
\hline Total number of genera & 97 & 42 & 106 & 17 & 57 & 37 & 34 \\
\hline Total genera in common with $\mathrm{CM}$ & & 28 & 39 & 14 & 43 & 27 & 28 \\
\hline Total genera in common with HF & 28 & & 13 & 7 & 21 & 12 & 14 \\
\hline
\end{tabular}

Although the connections with the Pennsylvanian faunas from the American midcontinent were rather poor (see Winkler Prins, 1983), there are definite links with the Permian reef faunas from Texas (e.g., Heteralosia, Diplanus, Altiplecus) and Oregon (Rugivestis; Fig. 2 (1)), which could have been through the Canadian Arctic. The presence of several taxa in Texas that may have been derived from northwestern Europe (cf. Mundy and Brunton, 1985) and which have no direct relatives known from the Canadian Arctic (nor from the Cantabrian Mountains) is puzzling, but the excellent preservation with their spines attached in specimens from Britain and Texas make a direct comparison with the less well-preserved Hare Fiord and Spanish material difficult. Furthermore, these specialised forms are rather rare and could have been missed (collecting has been less intensive in Spain and Ellesmere Island than in the British Isles and Texas). 


\section{Conclusions}

The Bashkirian-Moscovian basin with reefoid deposits in the Cantabrian Mountains has apparently played an important role in providing a niche for the survival of reef-related brachiopod faunas during the Pennsylvanian, bridging the gap between the Mississippian brachiopods from reefoid deposits in northern Europe and the Permian faunas from reefs in the Urals and Texas. Surprisingly, they have their counterpart on Ellesmere Island in the Canadian Arctic, another refuge for these brachiopods during the Bashkirian-Moscovian.

Also, the Cantabrian Mountains provided the first examples of some specialised brachiopods, such as the Incisiini (Regrantia nomen nudum), Avisirinx and Rugivestis, the latter genus being also present on Ellesmere Island.

\section{Acknowledgements}

The author gratefully acknowledges the constructive criticism of Dr. R.H. Wagner and of the referees Drs. H.C.H. Brunton and M.L. Martínez Chacón, which helped to improve the manuscript significantly. Figure 1 was expertly drawn by E.J. Bosch and J. Leloux is thanked for taking some of the photographs of Figure 2.

\section{References}

Amler, M.R.W. and Winkler Prins, C.F., 1999, Lower Carboniferous bivalves from the Cantabrian Mts (Spain), Scripta Geologica 120: 1-45.

Aretz, M., 2002, Habitatanalyse und Riffbildungspotential kolonialer rugoser Korallen im Unterkarbon (Mississippium) von Westeuropa, Kölner Forum für Geologie und Paläontologie 10: 1-155.

Aretz, M., and Herbig, H.G., 2003, Coral-rich bioconstructions in the Viséan (Late Mississippian) of Southern Wales (Gower Peninsula, UK), Facies 49: 221-242.

Babin, C., García-Alcalde, J., Gutiérrez-Marco, J.C., and Martínez Chacón, M.L., 1999, Conocardiacea (Mollusca, Rostroconchia) du Dévonien et du Carbonifère d'Espagne, Revue de Paléobiologie 18: 173-186.

Balthasar, U., and Amler, M.R.W., 2003, Silicified Foraminifera from the Lower Carboniferous Genicera Formation (Cantabrian Mountains, Northern Spain) and their palaeoenvironmental interpretation, Courier Forschungsinstitut Senckenberg 242: 1-19.

Bassett, M.G. and Bryant, C., 1993, The micromorphic rhynchonelloidean brachiopod Lambdarina from the type Dinantian, Journal of Paleontology 67: 518-527.

Becker, G., 1982, Fazies-anzeigende Ostracoden-Vergesellschaftungen aus dem frühen Oberkarbon des Kantabrischen Gebirges (N-Spanien), Neues Jahrbuch für Geologie und Paläontologie, Abhandlungen 164: 307-338.

Becker, G., Frankenfeld, H., and Schulze, R., 1979, Neue Daten zum Riffsterben im Oberdevon des Kantabrischen Gebirges (N-Spanien), Clausthaler Geologische Abhandlungen 30: 19-33. 
Bless, M.J.M. and Sánchez de Posada, L.C., 1973, Sobre la aparición de Ostrácodos nectónicos en la Cordillera Cantábrica, Breviora Geológica Astúrica 17: 25-30.

Bless, M.J.M. and Winkler Prins, C.F., 1972, Paleoecology and paleogeography of the Aegir Marine Band and its equivalents in North-western Europe, Compte Rendu Septième Congrès International de Stratigraphie et de Géologie du Carbonifère, Krefeld, 1971, 1: 231-239.

Bless, M.J.M. and Winkler Prins, C.F., 1973, Paleoecology of Upper Carboniferous strata in Asturias (N. Spain), Compte Rendu Septième Congrès International de Stratigraphie et de Géologie du Carbonifère, Krefeld, 1971, 2: 129-137.

Boll, F.Ch., 1985, Rugose Korallen der Flachwasser-Fazies im Oberkarbon des Kantabrischen Gebirges (Nordspanien), Palaeontographica, Abteilung A 190: 1-81.

Boogaard, M. van den and Bless, M.J.M., 1985, Some conodont faunas from the Aegiranum Marine Band, Proceedings Koninklijke Nederlandse Akademie van Wetenschappen, Serie B 88: 133-154.

Bowman, M.B.J., 1979, The depositional environments of a limestone unit from the San Emiliano Formation (Namurian/Westphalian), Cantabrian Mts., NW Spain, Sedimentary Geology 24: 25-43.

Bowman, M.B.J., 1982, The stratigraphy of the San Emiliano Formation and its relationship to other Namurian/Westphalian A sequences in the Cantabrian Mts., NW Spain, Trabajos de Geología 12: 23-35.

Bowman, M.B.J., 1985, The sedimentology and palaeogeographic setting of late NamurianWestphalian A basin-fill successions in the San Emiliano and Cármenes areas of NW León, Cantabrian Mts, NW Spain, in: Lemos de Sousa, M.J. and Wagner, R.H. (eds), Papers on the Carboniferous of the Iberian Peninsula (Sedimentology, Stratigraphy, Palaeontology, Tectonics and Geochronology). Anais da Faculdade de Ciências, Universidade do Porto, 64 (Suppl.): 117-169.

Bridges, P.H., Gutteridge, P., and Pickard, N.A.H., 1995, The environmental setting of early Carboniferous mud-mounds, in: Monty, C.L.V., Bosence, D.W.J., Bridges, P.H., and Pratt, B.R. (eds), Carbonate Mud-Mounds Their Origin and Evolution. International Association of Sedimentologists Special Publication 23: 171-190.

Brouwer, A., 1964, Devonian biostromes and bioherms of the southern Cantabrian Mountains, northwestern Spain, in: Straaten, L.M.J.U. van (ed.), Deltaic and Shallow Marine Deposits. Developments in Sedimentology 1: 48-53.

Brouwer, A. and Ginkel, A.C. van, 1964, La succesion carbonifère dans la partie méridionale des Montagnes Cantabriques, Compte Rendu V Congrès International de Stratigraphie et de Géologie du Carbonifère, Paris, 1962, 1: 307-319.

Brunton, C.H.C., 1966, Silicified brachiopods from the Visean of County Fermanagh, I. Bulletin of the British Museum (Natural History), Geology Series 12: 175-243.

Brunton, C.H.C., 1968, Silicified brachiopods from the Visean of County Fermanagh, II, Bulletin of the British Museum (Natural History), Geology Series, 16: 1-70.

Brunton, C.H.C., 1984, Silicified brachiopods from the Viséan of County Fermanagh, Ireland (III). Rhynchonellids, Spiriferids and Terebratulids, Bulletin of the British Museum (Natural History), Geology Series 38: 27-130.

Brunton, C.H.C., 1985, Some Carboniferous brachiopod distributions, Compte Rendu Dixième Congrès International de Stratigraphie et de Géologie du Carbonifère, Madrid, 1983, 4: 75-81.

Brunton, C.H.C., 1987, The palaeoecology of brachiopods, and other faunas, of Lower Carboniferous (Asbian) limestones in West Fermanagh, Irish Journal of Earth Sciences 8: $97-112$. 
Brunton, C.H.C., 1996, A new protorichthofenoid brachiopod (Productida) from the Upper Carboniferous of the Urals, Russia, Bulletin of the Natural History Museum London (Geology) 51: 51-59.

Brunton, C.H.C. and Champion, C., 1974, A Lower Carboniferous brachiopod fauna from the Manifold Valley Staffordshire, Palaeontology 17: 811-840.

Brunton, C.H.C., Lazarev, S.S., Grant, R.E., and Jin Yu-gan, 2000, Productidina, in: Williams, A. et al. Treatise on Invertebrate Paleontology. Part H. Brachiopoda Revised, Volume 3: Linguliformea, Craniiformea, and Rhynchonelliformea (part). The Geological Society of America and The University of Kansas, Boulder, CO and Lawrence, KA, pp. 424-609.

Brunton, C.H.C. and Mundy, D.J.C., 1985, Growth and shell shape in Productacean Brachiopods, Bulletin of the British Museum of Natural History (Geology) 38: 273-281.

Brunton, C.H.C. and Mundy, D.J.C., 1986, Some Dinantian chonopectinid productaceans (Brachiopoda) from the British Isles, Proceedings of the Yorkshire Geological Society 46: $1-10$.

Brunton, C.H.C. and Mundy, D.J.C., 1988, Strophalosiacean and aulostegacean productoids (Brachiopoda) from the Craven Reef Belt (late Viséan) of North Yorkshire, Proceedings of the Yorkshire Geological Society 47: 55-88.

Brunton, C.H.C. and Mundy, D.J.C., 1994, A new productoid brachiopod from the late Visean Craven Reef Belt of North Yorkshire, Proceedings of the Yorkshire Geological Society 50: 119-123.

Brunton, C.H.C., Mundy, D.J.C., and Lazarev, S.S., 1994, Productellid and Plicatiferid (Productoid) Brachiopods from the Lower Carboniferous of the Craven Reef Belt, North Yorkshire, Bulletin of the British Museum of Natural History (Geology) 49: 99-119.

Brunton, C.H.C. and Tilsley, J.W., 1991, A checklist of brachiopods from Treak Cliff, Derbyshire, with reference to other Dinantian (Lower Carboniferous) localities, Proceedings of the Yorkshire Geological Society 48: 287-295.

Carballeira, J., Corrales, I., Valladares, I., Naval, A., Ruiz, F., Lorenzo, S., Martínez Chacón, M.L., Méndez, C., Sánchez de Posada, L.C., and Truyols, J., 1985, Aportaciones al conocimiento de la estratigrafía de la Formación San Emiliano (Carbonífero, Cordillera Cantábrica) en su área-tipo, Compte Rendu Dixième Congrès International de Stratigraphie et de Géologie du Carbonifère, Madrid, 1983, 1: 345-362.

Carter, J.L. and Poletaev, V.I., 1998, Atokan (Late Bashkirian or Early Moscovian) brachiopods from the Hare Fiord Formation of Ellesmere Island, Canadian Arctic Archipelago, Annals of the Carnegie Museum 67: 105-180.

Comte, P., 1938, La transgression du Famennien supérieur dans la Cordillère Cantabrique, Compte Rendu de l'Académie des Sciences 206: 1741-1743.

Cooper, G.A. and Grant, R.E., 1972-1977, Permian Brachiopods of West Texas, I-VI., Smithsonian Contributions to Paleobiology 14: 1-231; 15: 233-793; 19: 795-1921; 21 : 1923-2607; 24: 2609-3159; 32: 3161-3370.

Defrance, M.J.L., 1826, Article Productus, Dictionaire des Sciences Naturelles, Paris, 43: 349-355.

Delépine, G. and Llopis Lladó, N., 1956, Nouvelle faune Carbonifère à Latores (Asturies, Espagne), Comptes Rendus sommaires des Séances de la Société Géologique de France 1956, pp. 106-108.

Eder, W. and Franke, W., 1982, Death of Devonian reefs, in: Kullmann, J., Schönenberg, R., and Wiedmann, J. (eds), Subsidenz-Entwicklung im Kantabrischen Variszikum und an passiven Kontinentalrändern der Kreide. Teil I Variszikum. Neues Jahrbuch für Geologie und Paläontologie, Abhandlungen 163: 241-243. 
Eichmüller, K., 1985, Die Valdeteja Formation: Aufbau und Geschichte einer oberkarbonischen Karbonatplattform (Kantabrisches Gebirge, Nordspanien), Facies 13: 45-154.

Eichmüller, K., 1986, Some Upper Carboniferous (Namurian; Westphalian) Lithostratigraphic units in Northern Spain, results and implications of an environmental interpretation, Boletín del Instituto Geológico y Minero de España 97: 590-607.

Eichmüller, K. and Seibert, P., 1984, Faziesentwicklung zwischen Tournai und Westfal D im Kantabrischen Gebirge (NW-Spanien), Zeitschrift der Deutschen Geologischen Gesellschaft 135: 163-191.

Fernández, L.P., 1993, La Formación San Emiliano (Carbonífero de la Zona Cantábrica, NO de España): estratigrafía y extensión lateral. Algunas implicaciones paleogeográficas, Trabajos de Geología 19: 97-122.

Fernández López, M.G., and Sánchez de Posada, L.C., 1987, Hollinomorpha y Kirkbyocopina (Ostracoda) del Bashkiriense del N. de León (Cordillera Cantábrica, NW. de España), Revista Española de Micropaleontología 19: 465-485.

Flajs, G., Hüssner, H., Fenninger, A., and Hubmann, B., 1996, Upper Permian Richthofeniid buildups of Chios Island (Aegean Sea) - preliminary report, Jahrbuch der Geologischen Bundesanstalt 139: 21-28.

Frankenfeld, H., 1982, Das Ende der devonischen Riff-Fazies im nordspanischen Variszikum, Neues Jahrbuch für Geologie und Paläontologie, Abhandlungen, 163 (2): 238-241.

Gandl, J., 1987, Trilobiten aus dem höheren Namur und tieferen Westfal, Abhandlungen der Senckenbergischen Naturforschenden Gesellschaft 543: 1-79.

García Bartolomé, A., Rodríguez, R.M., and Sánchez de Posada, L.C., 2003, Miosporas de los niveles superiores de la sucesión de la Playa de la Huelga (Carbonífero del E de Asturias, España), Revista Española de Micropaleontología 35: 29-42.

García-Bellido, D.C. and Rigby, K., 2004, Devonian and Carboniferous sponges from Spain. Journal of Paleontology 78: 431-455.

García-Bellido, D.C. and Rodríguez, S., 2004, Palaeobiogeographical relationships of poriferan and coral assemblages during the late Carboniferous and the closure of the western Palaeotethys Sea-Panthalassan Ocean connection, Palaeogeography, Palaeoclimatology, Palaeoecology 219: 321-331.

Ginkel, A.C. van, 1965, Spanish Carboniferous fusulinids and their significance for correlation purposes, Leidse Geologische Mededelingen 34: 175-225.

Ginkel, A.C. van, and Villa, E., 1996, Palaeontological data of the San Emiliano Formation (Cantabrian Mountains, Spain) and their significance in the Carboniferous chronostratigraphy, Geobios 29: 149-170.

Gulyás-Kis, Cs., 2004, Paleobiogeographic analysis of Moscovian (Pennsylvanian) brachiopods Productida, Orthotetida, Orthida, Rhynchonellida from Bükk Mts, Hungary, Hantkeniana 4: 17-35.

Harper, D.A.T. and Jeffrey, A.L., 1996, Mid-Dinantian brachiopod biofacies from western Ireland, Geological Society Special Publication 107: 427-436.

Jordan, H. and Bless, M.J.M., 1970, Nota preliminar sobre los ostrácodos de la Formación Vegamián, Breviora Geológica Astúrica 4: 37-44.

Julivert, M., 1967, La ventana del Río Monasterio y la terminación meridional del Manto del Ponga, Trabajos de Geología 1: 59-67.

Julivert, M., 1971, Décollement tectonics in the Hercynian cordillera of Northwest Spain, American Journal of Science 270: 1-29.

Kullmann, J. and Rodríguez, S., 1986, Hornförmige Einzelkorallen (Rugosa) aus früh oberkarbonischen Flachwasser-Sedimenten im Kantabrische Gebirge (Nordspanien), Neues Jahrbuch für Geologie und Paläontologie, Monatshefte 1986: 293-306. 
Kullmann, J. and Rodríguez, S., 1994, Biostratigraphic range and biogeographic relationships of the undissepimented solitary corals from the Picos de Europa Formation (Moscovian, Cantabrian Mountains, NW Spain), Courier Forschungsinstitut Senckenberg 172: 15-22.

Kutorga, S.S., 1844, Zweiter Beitrag zur Paläontologie Russlands, Verhandlungen der Russisch-kaiserlichen Mineralogischen Gesellschaft 1844: 62-104.

Lees, A. and Miller, J., 1995, Waulsortian banks, in: Monty, C.L.V., Bosence, D.W.J., Bridges, P.H., and Pratt, B.R. (eds), Carbonate Mud-Mounds Their Origin and Evolution. International Association of Sedimentologists Special Publication 23: 191-271.

Lotze, F., 1945, Zur Gliederung der Varisziden der Iberischen Meseta, Geotektonische Forschungen 6: 1-12

Martínez Chacón, M.L., 1975, Avisyrinx n. gen. (Syringothyrididae, Brachiopoda) del Carbonífero de Asturias (España), Breviora Geológica Astúrica 19: 33-40.

Martínez Chacón, M.L., 1977, New Carboniferous stenoscismatacean brachiopods from Oviedo and León, Spain, Palaeontology 20: 209-223.

Martínez Chacón, M.L., 1978a, Nuevos braquiópodos de la Formación San Emiliano (Cordillera Cantábrica, NO. de España), Breviora Geológica Astúrica 22: 17-32.

Martínez Chacón, M.L., 1978b, Syringothyridacea (Brachiopoda) del Carbonífero de la Cordillera Cantábrica (N de España), Trabajos de Geología 10: 317-330.

Martínez Chacón, M.L., 1979, Braquiópodos carboníferos de la Cordillera Cantábrica (Orthida, Strophomenida y Rhynchonellida). Memorias del Instituto Geológico y Minero de España 96: 291 pp.

Martínez Chacón, M.L., 1988, Braquiópodos del Carbonífero Medio del corte de la Playa de La Huelga (Asturias, NW de España), Geogaceta 5: 13-16.

Martínez Chacón, M.L., 1990, Braquiópodos carboníferos de la costa E de Asturias (España). I: Orthida, Strophomenida, Rhynchonellida y Athyridida, Revista Española de Paleontología 5: 91-110.

Martínez Chacón, M.L., 1991, Braquiópodos carboníferos de la costa E de Asturias (España). II: Spiriferida y Terebratulida, Revista Española de Paleontología 6: 59-88.

Martínez Chacón, M.L. and Bahamonde, J.R., in press, Brachiopods in the steep slope of a Pennsylvanian carbonate platform (Sierra del Cuera, Asturias, N. Spain), Proceedings $V$ International Brachiopod Congress, Copenhagen, 2005.

Martínez Chacón, M.L., Menéndez Álvarez, J.R., Sánchez de Posada, L.C., and Truyols, J., 1985, Aportaciones al conocimiento de la Formación Ricacabiello (Carbonífero de la Zona Cantábrica, $\mathrm{N}$ de España) y su contenido paleontológico, Trabajos de Geología 15: 53-65.

Martínez Chacón, M.L. and Winkler Prins, C.F., 1977, A Namurian brachiopod fauna from Meré (Province of Oviedo, Spain), Scripta Geologica 39: 1-67.

Martínez Chacón, M.L. and Winkler Prins, C.F., 1986, The brachiopod fauna of the San Emiliano Formation (Cantabrian Mountains, NW Spain) and its connection with other areas, Compte Rendu Neuvième Congrès International de Stratigraphie et de Géologie du Carbonifère, Washington and Champaign-Urbana, 1979, 5: 233-244.

Martínez Chacón, M.L. and Winkler Prins, C.F., 1993, Carboniferous brachiopods and the palaeogeographic position of the Iberian Peninsula, Compte Rendu XII Congrès International de Stratigraphie et de Géologie du Carbonifère et Permien, Buenos Aires, 1991, 1: 573-580.

Martínez Chacón, M.L. and Winkler Prins, C.F., 2000, New Rugosochonetidae (Brachiopoda) from the upper Bashkirian and Moscovian of the Cantabrian Mountains (N Spain), Revista Española de Paleontología 15: 219-232. 
Martínez Chacón, M.L. and Winkler Prins, C.F., 2006a, Braquiópodos de la Formación Valdeteja (Pensilvánico, Cordillera Cantábrica, $\mathrm{N}$ de España), in: Fernández-Martínez (ed.), XXII Jornadas de la Sociedad Española de Paleontología y simposios de los proyectos PICG 493, 503, 499, y 467, Libro de Resúmenes: 145-147.

Martínez Chacón, M.L. and Winkler Prins, C.F., 2006b (in press), Medio siglo de estudio de los Braquiópodos del yacimiento de Latores, I Congreso de Estudios Asturianos, Oviedo, 2006.

Martínez Díaz, C., 1969, Carbonífero marino de la Zona de Riosa (Asturias, España), Revista Española de Micropaleontología 1: 59-80.

Méndez, C.A. and Menéndez Álvarez, J.R., 1985, Conodontos carboníferos de las regiones del Manto del Ponga y Picos de Europa (Oriente de Asturias, N de España), Compte Rendu Dixième Congrès International de Stratigraphie et de Géologie du Carbonifère, Madrid, 1983, 1: 71-82.

Méndez-Bedia, I., Soto, F., and Fernández-Martínez, E., 1994, Devonian reef types in the Cantabrian Mountains (NW Spain) and their faunal composition, Courier Forschungsinstitut Senckenberg 172: 161-184.

Minwegen, E., 2001, Die Biokonstruktionen im Pennsylvanium des Kantabrischen Gebirges (Nordspanien), Kölner Forum für Geologie und Paläontologie 9: 1-139.

Mohanti, M., 1972, The Portilla Formation (Middle Devonian) of the Alba Syncline, Cantabrian Mountains, Prov. León, northwestern Spain: carbonate facies and rhynchonellid palaeontology, Leidse Geologische Mededelingen 48: 135-205.

Mundy, D.J.C. and Brunton, C.H., 1985, Morphological Similarities in Some British Dinantian and Texas Permian Reef Brachiopods, Compte Rendu Neuvième Congrès International de Stratigraphie et de Géologie $d u$ Carbonifère, Washington and Champaign-Urbana, 1979, 5: 225-232.

Navarro, D., Leyva, F., and Villa, E., 1986, Cambios laterales de facies en el Carbonífero del Oriente de Asturias (Cordillera Cantábrica, Norte de España), Trabajos de Geología 16: $87-102$.

Parga, J.R., 1969, Consideraciones sobre la erosión Fameniense en la Cordillera Cantábrica, Breviora Geológica Astúrica 13: 46-48.

Porta, G. della, Kenter, J.A.M., and Bahamonde, J.R., 2004, Depositional facies and stratal geometry of an Upper Carboniferous prograding and aggrading high-relief carbonate platform (Cantabrian Mountains, N Spain), Sedimentology 51: 267-295.

Rácz, L., 1964, Carboniferous calcareous algae and their associations in the San Emiliano and Lois-Ciguera formations (Prov. León, NW Spain), Leidse Geologische Mededelingen 31: $1-112$.

Radig, F., 1962, Ordovizium/Silurium und die Frage prävariszischer Faltungen in Nordspanien, Geologische Rundschau 52: 346-397.

Ramovš, A., 1971, Connections of the Upper Carboniferous brachiopod faunas from the Carnic Alps and Karavanke Mountains with those of the Cantabrian Mountains (Spain), in: R.H. Wagner (ed.), The Carboniferous of Northwest Spain, 2. Trabajos de Geología 4: 373-377.

Reuther, C.-D., 1977, Das Namur im südlichen Kantabrischen Gebirge (Nordspanien); Krustenbewegungen und Faziesdifferenzierung im Übergang Geosynklinale - Orogen, Clausthaler Geologische Abhandlungen 28: 1-122.

Reijers, T.J.A., 1973, Hinge movements influencing deposition during the Upper Devonian in the Esla area of the Cantabrian Mountains, Spain, Leidse Geologische Mededelingen 53: 13-21. 
Riding, H., 1978, Donezella bioherms in the Carboniferous of the southern Cantabrian Mountains, Spain, Bulletin du Centre de Recherches d'Exploration Petrolifère ElfAquitaine 3: 787-794.

Rodríguez, S., 1996, Development of coral reef-facies during the Viséan at Los Santos de Maimona, SW Spain, in: Strogen, P., Somerville, I.D., and Jones, G.L. (eds), Recent Advances in Lower Carboniferous Geology. Geological Society Special Publication 107: $145-152$.

Rodríguez, S. and Ramírez, C., 1987, Los siringopóridos de la sección de la Playa de la Huelga (Carbonífero, Asturias, Noroeste de España), Boletín de la Real Sociedad Española de Historia Natural, sección Geológica 83: 57-82.

Rodríguez, S., Sando, W.J. and Kullmann, J., 1986, Utility of corals for biostratigraphic and zoogeographic analyses of the Carboniferous in the Cantabrian Mountains, Northern Spain, Trabajos de Geología 16: 37-60.

Rodríguez Fernández, L.R., 1993, Tectonosedimentary evolution of a Carboniferous foreland basin related with arcuated fold-thrust belt. The example of NW Iberian Variscan belt, Compte Rendu XII Congrès International de Stratigraphie et de Géologie du Carbonifère et Permien, Buenos Aires, 1991, 1: 435-445.

Romano, M., 1971, A new Proetid trilobite from the Lower Westphalian of North-West Spain. in: Wagner, R.H. (ed.), The Carboniferous of Northwest Spain, 2. Trabajos de Geología 4: 379-383.

Sánchez de Posada, L., 1976, Quelques remarques au sujet de la répartition des faunes d'Ostracodes carbonifères dans la chaîne Cantabrique, Annales de la Société Géologique du Nord 96: 407-412.

Sánchez de Posada, L.C. and Bless, M.J.M., 1999, Hollinéllidos del Moscoviense Superior (Carbinífero) de la Playa de la Huelga (Zona Cantábrica, N de España): fauna y bioestratigrafía, Revista Española de Paleontología número extraordinario: 29-41.

Sánchez de Posada, L.C. and Fohrer, B., 2001, Kirkbyoid ostracodes (Upper Carboniferous) from the Cantabrian Mountains (Spain) and Carnic Alps (Austria and Italy), Journal of Paleontology 75: 972-984.

Sánchez de Posada, L.C., García-Lopez, S., and Villa, E., 1998, The Paleozoic of the Cantabrian Zone, in: Lamolda, M.A. (ed.), Libro Guía. 24 Coloquio Europeo de Micropaleontología, Bilbao, Spain, pp. 11-22.

Sánchez de Posada, L.C., Martínez Chacón, M.L., Méndez, C.A., Menéndez Álvarez, J.R., and Villa, E., 1993, El Carbonífero de las regiones de Picos de Europa y Manto del Ponga (Zona Cantábrica, $\mathrm{N}$ de España): fauna y bioestratigrafía, Revista Española de Paleontología número extraordinario: 89-108.

Sánchez de Posada, L.C., Martínez Chacón, M.L., Méndez, C.A., Menéndez Álvarez, J.R., Río, L.M., Rodríguez, S., Truyols, J., and Villa, E., 1996, El Carbonífero marino del ámbito Astur-Leonés (Zona Cantábrica): síntesis paleontológica, Revista Española de Paleontología número extraordinario: 82-96.

Sánchez de Posada, L.C., Martínez Chacón, M.L., Méndez, C.A., and Villa, E., 2002, Rasgos paleontológicos del Carbonífero marino cantábrico, in: Gámez Vintaned, J.A. and Liñan, E. (eds), Memorias de las VII Jornadas Aragonesas de Paleontología. La era paleozóica. El desarrollo de la vida marina. Homenaje al Prof. Jaime Truyols. Institución "Fernando el Católico", Zaragoza, Spain, pp. 191-222.

Sano, H., Fujii, S., and Matsuura, F., 2004, Response of Carboniferous-Permian mid-oceanic seamount-capping buildup to global cooling and sea-level change: Akiyoshi, Japan, Palaeogeography, Palaeoclimatology, Palaeoecology 213: 187-206. 
Sommerville, I.D., Strogen, P., Jones, G.L1., and Somerville, H.E.A., 1996. Late Viséan buildups at Kingscourt, Ireland: possible precursors for Upper Carboniferous bioherms, Geological Society Special Publication 107: 127-144.

Stubblefield, C.J., 1960, Sessile marine organisms and their significance in pre-Mesozoic strata, Quarterly Journal of the Geological Society of London 116: 219-238.

Tschernyschew, Th., 1902, Die obercarbonische Brachiopoden des Ural und des Timan. Mémoires du Comité Géologique 16 (2): 749 pp.

Twenhofel, W.H., 1950, Coral and other organic reefs in geologic column, Bulletin of the American Association of Petroleum Geologists 34: 182-202.

Verneuil, E. de, 1840, Sur quelques espèces intéressantes de brachiopodes des terrains anciens, Bulletin de la Société Géologique de France 11: 257-262.

Villa, E., 1982, Observaciones sobre la edad de la Formación Valdeteja (Carbonífero de la Cordillera Cantábrica) en su area-tipo, Revista Española de Micropaleontología 14: 63-72.

Villa, E., 1989, Foraminíferos Bashkirienses de la Sierra del Sueve (Cuenca Carbonífera Central, Zona Cantábrica, NW de España), Revista Española de Paleontología 4: 81-89.

Villa Otero, E., 1995, Fusulináceos Carboníferos del Este de Asturias ( $N$ de España). Biostratigraphie du Paléozoïque 13: 1-261.

Villa, E. and Ginkel, A.C. van, 1999, First record of Gzhelian fusulinaceans from the Carboniferous of northern Spain, Revista Española de Paleontología número extraordinario: 205-216.

Villa, E., Sánchez de Posada, L.C., Martínez Chacón, M.L., and Stavros, Ch., 2001, Foraminifera and biostratigraphy of the Valdeteja Formation stratotype (Carboniferous, Cantabrian Zone, NW Spain), Facies 45: 59-86.

Wagner, R.H., 2004, The Iberian Massif: a Carboniferous assembly, Journal of Iberian Geology 30: 93-108.

Wagner, R.H. and Bowman, M.B.J., 1983, The position of the Bashkirian/Moscovian boundary in West European chronostratigraphy, Newsletter on Stratigraphy 12: $132-161$.

Wagner, R.H. and Martínez García, E., 1974, The relation between geosynclinal folding and foreland movements in Northwest Spain, Studia Geológica 7: 131-158.

Wagner, R.H., Sánchez de Posada, L.C., Martínez Chacón, M.L., Fernández, L.P., Villa, E., and Winkler Prins, C.F., 2002, The Asturian Stage: a preliminary proposal for a replacement of the Westphalian D. Canadian Society of Petroleum Geologists, Memoir 19: 832-850.

Wagner, R.H. and Winkler Prins, C.F., 1985, The Cantabrian and Barruelian stratotypes: a summary of basin development and biostratigraphic information, in: Lemos de Sousa, M.J. and Wagner, R.H. (eds), Papers on the Carboniferous of the Iberian Peninsula. Anais da Faculdade de Ciências, Universidade do Porto, 64 (Suppl.): 359-410.

Wagner, R.H. and Winkler Prins, C.F., 1999, Carboniferous stratigraphy of the Sierra del Brezo in northern Palencia (Cantabrian Mts, NW Spain): evidence of major uplifts, Trabajos de Geología 21: 385-403.

Wagner, R.H. and Winkler Prins, C.F., 2002, Tectonics vs. cyclothems: Carboniferous sedimentation in the Cantabrian Mountains, Spain, Canadian Society of Petroleum Geologists, Memoir 19: 228-238.

Wagner, R.H., Winkler Prins, C.F., and Riding, R.E., 1971, Lithostratigraphical units of the lower part of the Carboniferous in northern León, Spain (with a Note on some goniatite faunas by C.H.T. Wagner-Gentis), in: R.H. Wagner (ed.), The Carboniferous of Northwest Spain, 2. Trabajos de Geología 4: 603-633. 
Wahlman, G.P., 2002, Upper Carboniferous-Lower Permian (Bashkirian-Kungurian) mounds and reefs, in: Kiessling, W., Flügel, E., and Golonka, J. (eds), Phanerozoic Reef Patterns, SEPM Special Publication 72: 271-338.

Webb, G.E., 2002, Latest Devonian and Early Carboniferous reefs: depressed reef building after the Middle Paleozoic collapse, In: Kiessling, W., Flügel, E., and Golonka, J. (eds), Phanerozoic Reef Patterns, SEPM Special Publication 72: 239-269.

West, R.R., 1988, Temporal changes in Carboniferous reef mound communities, Palaios 3: 152-169.

Winkler Prins, C.F., 1968, Carboniferous Productidina and Chonetidina of the Cantabrian Mountains (NW Spain): systematics, stratigraphy and palaeoecology, Leidse Geologische Mededelingen 43: 41-126.

Winkler Prins, C.F., 1971, The road section East of Valdeteja with its continuation along the Arroyo de Barcaliente (Curueño River Valley, León), in: Wagner, R.H. (ed.), The Carboniferous of Northwest Spain, 2. Trabajos de Geología 4: 677-684.

Winkler Prins, C.F., 1983, A general review of the Carboniferous brachiopods from the Cantabrian Mountains (North Spain), in: Lemos de Sousa, M.J. (ed.), Contributions to the Carboniferous Geology and palaeontology of the Iberian Peninsula, Faculdade de Ciências, Universidade do Porto, Porto, Portugal, pp. 69-91.

Winkler Prins, C.F., 1991, Brachiopod distributions and the palaeogeographic reconstructions for the Carboniferous, Compte Rendu XI International Congress on Carboniferous Stratigraphy and Geology, Beijing, 1987, 2: 382-390.

Winkler Prins, C.F. and Martínez Chacón, M.L., 1999, The brachiopod fauna of the Lower Carboniferous Vegamián Formation (Cantabrian Mts, Spain); part 1: Introduction, Linguliformea, Revista Española de Micropaleontología número extraordinario: 173-183.

Wolfenden, E.B., 1958, Paleoecology of the Carboniferous reef complex and shelf limestones in northwest Derbyshire, England, Bulletin of the Geological Society of America 69: 871-898. 